\title{
Antologi Pnisi
}

$\stackrel{0}{\circ}$

$z$
$<$
3
$<$
$\frac{1}{6}$
5
4
un

(5) (50)

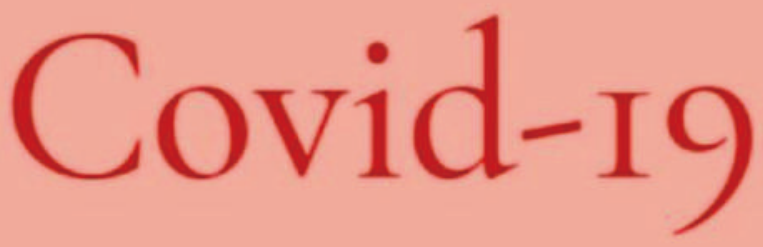

RADANG \& LADANG KEHIDUPAN

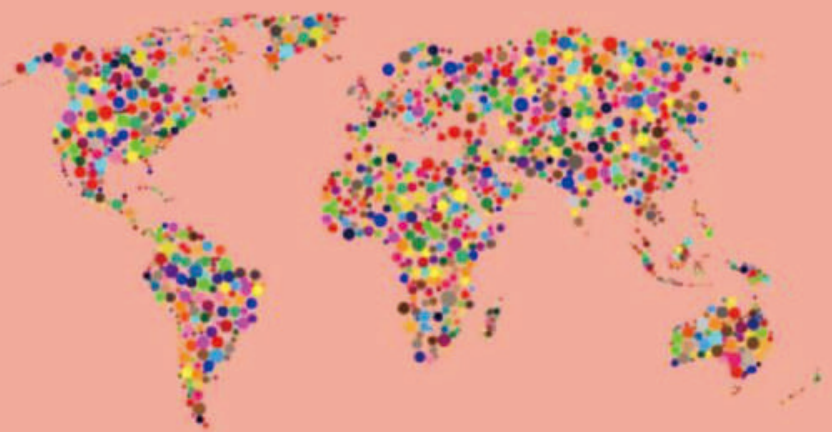

Editor:

Rebbeca Arju

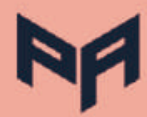


Sastrawan Covid-19

Antologi Puisi

Covid-19

RADANG \& LADANG KEHIDUPAN

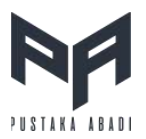

2020 


\section{Antologi Puisi: \\ COVID-19 RADANG \& LADANG KEHIDUPAN}

Copyright (C) 2020 Sastrawan Covid-19

Hak Cipta dilindungi oleh undang-undang. Pertama kali diterbitkan di Indonesia dalam bahasa Indonesia oleh Pustaka Abadi. Hak moral atas buku ini dimiliki oleh Penulis. Hak ekonomi atas buku ini dimiliki oleh Penulis dan Penerbit sesuai dengan perjanjian. Dilarang mengutip atau memperbanyak baik sebagian atau keseluruh isi buku dengan cara apapun tanpa izin tertulis dari Penerbit.

Penulis:

\section{Sastrawan Covid-19}

Editor:

\section{Barotun Mabaroh (Rebbeca Arju)}

Design Cover \& Layout: Muhsin

Diterbitkan Oleh:

PUSTAKA ABADI

Anggota IKAPI No.185/JTI/2017

Jl. Jawa II-D No.1, Jember, Jawa Timur, 68121

Email: redaksi@pustakaabadi.com

Website: www.pustakaabadi.com

Cetakan Pertama, Mei 2020

$14 \mathrm{~cm} \times 20 \mathrm{~cm} ; 160$ page

ISBN: 978-623-7628-44-6 
Untuk para malaikat kehidupan

Ayah...Ibu...

Semoga Allah mengampuni

menyayangi

sebagaimana kasihmu

di masa kecil kami.

Dunia segera terbebas dari pandemi... 


\section{Kata Pengantar}

Duji syukur bagi Allah, muara keromantisan, kelembutan, dan kepercayaan yang telah mengutus Rasul mulia untuk membina dan memberi teladan umat semesta. Alhamdulillah antologi ini merupakan luapan hati selama menjalani masa bersejarah, pandemi covid-19. Ada gerakan yang ikhlas dan tulus dari para kontributor sehingga antologi ini memiliki ragam warna dan ekspresi; pasrah, marah, curiga, harapan, tangis, pengalaman, kemungkinan, dan sebagainya. Para kontributor dalam antologi ini berasal dari berbagai kalangan, mulai dari pelajar, pedagang, guru, dosen, pengasuh pesantren dan para profesor. Antologi ini sengaja kami susun secara alfabetik judul puisi karena motivasi untuk toleransi dan apresiasi kepada para kontributor tanpa terkecuali. Namun, di lembar ini, kami menghaturkan ta'dhim tertinggi untuk para guru kami yang merestui dan tulus berkontribusi dalam antologi covid-19 ini yaitu Prof. Dr. KH. Moh. Ali Aziz, M.Ag. (Guru Besar Bidang Da'wah, UIN Sunan Ampel Surabaya), Prof. Dr. H. Abdul Haris, M.Ag. (Rektor UIN Maulana Malik Ibrahim Malang), Prof. H. Effendi Kadarisman, M.A, Ph.D (Guru Besar dan Pakar 
Etnopuitika Universitas Negeri Malang), Prof. $H$. Mohammad Adnan Latief, M.A, Ph.D (Guru Besar Bidang Pembelajaran Bahasa Inggris, Fakultas Sastra, Universitas Negeri Malang), Prof. Hj. Utami Widiati, M.A, Ph.D (Guru Besar dalam bidang TEFL (Pembelajaran Bahasa Inggris sebagai Bahasa Asing), Fakultas Sastra, Universitas Negeri Malang,), Prof. Dra. Jenny Lukito Setiawan, Ph.D (Guru Besar Bidang Psikologi, Universitas Ciputra, Surabaya), Dr. KH. Sakban Rosidi, M.Si (Direktur Pascasarjana IKIP Budi Utomo Malang), Dr. Mundi Rahayu, M.Hum (UIN Maulana Malik Ibrahim Malang), Dr. Eng. Leny Yuliati, S.Si., M.Eng. (Dosen Peneliti, Fakultas Sains dan Teknologi, Universitas Ma Chung, Malang), Dr. H. Sugeng Pradikto, M.Pd (Rektor Universitas PGRI Wiranegara Pasuruan), Dr. Sony Sukmawan, M.Pd (Kajur Pendidikan Bahasa Universitas Brawijaya), Dr. KH. Halimy Zuhdy, M.Pd, M.A (UIN Maulana Malik Ibrahim Malang), Dr. Laily Fitriani, M.Pd (UIN Maulana Malik Ibrahim Malang), serta Dr. H.Daryono, M.Pd (Dosen Universitas PGRI Wiranegara Pasuruan). Tiap kata dalam antologi ini semoga dapat memberi makna positif dan memberi semangat bagi seluruh masyarakat. Tim kami, M99 Management, akan dengan sangat terbuka terhadap segala kritik dan masukan untuk setiap goresan tinta yang termaktub di antologi ini. Teriring doa, semoga Allah meridhoi, memberi sayang, dan mengakhiri pandemi. Amin.

Mei 2020

Rebbeca Arju 


\section{Daftar Isi}

Untaian Dedikasi ...........................................................................

Kata Pengantar ..................................................................................

Agama dan Musibah

Abdul Haris .......................................................................................1

Apa yang akan Terjadi

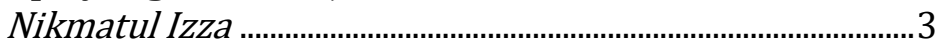

APD

Laily Fitriani........................................................................

Asaku dalam Keheningan

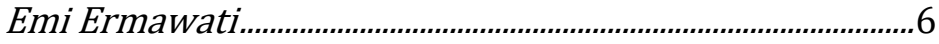

Bagiku, KORONA itu Kerrong Mekkah Madina, Bagimu?

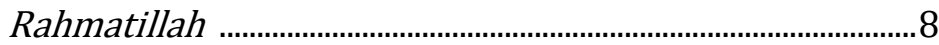

Belajar dari Covid

Utami Widiati................................................................................11

Bendera Syahid

M. Alifudin Ikhsan ..................................................................13

Berlalu

Shohib Cinta .......................................................................... 
Bocah dan Rindu

Maya Rayungsari ..................................................................16

Bukan Nekad tapi Mendekat

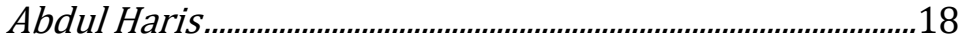

Celoteh Hati Bisu

Ilmiatur Rosidah

Cinta Tegar di Tengah Corona

Jenny Lukito Setiawan

Corona

Choirul Rozi 24

Corona, si Kuyang dan Sinar Rosul

Rebbeca Arju.

C-Sembilan Belas

Sugeng Pradikto .28

Diam

Maria Ulfa

Dilema Pandemi

Maya Rayungsari

Doa Paling Mustajab

Fitri Kharisma Putri.

Dunia dalam Duka

Ani Fiani. 34

Empat Kisah Selepas Ziarah

Sakban Rosidi.

Gemuruh

Rebbeca Arju.

Gugur Bunga

Bintang Soraya 
Hilanglah

Any Ikawati.

Hitamnya Sentilan MU

Eko Pujiati

.44

Hitung Sendiri

Rebbeca Arju

Ikatan Kita dan Corona

Leny Yuliati

Kami Tak Berdaya

Zaidatun Elif .

Kau Rona

Murasaki.

Kiana Berkelana

Dina Amaliyah Mushthoza. .54

Kisah Perjuangan Cinta Sejoli

Abdul Haris. .56

Korona, Aku Tak Tahu

Halimy Zuhdi 58

Kun Fayakuun

Mohammad Adnan Latief.

Laa Ilaha Illa Corona

Syukron Makmun

Lakon Terdepan

Rebbeca Arju 66

Mahkota Itu

Effendi Kadarisman

Makhluk Pencipta

Miftakhul Khoiri. 
Mata Ketiga

Azizah Hefni

\section{Mbok, Aku Ora Iso Mulih}

Daryono.

Negeri Ngeri

Rebbeca Arju.

80

Negeriku Sedang Sakit

Ika Pustpita

Nyanyian Semesta

Tri Kristianti. .83

\section{Pagebluk Corona}

Junaidi Abdillah.

\section{Pahlawan Bermasker}

Shohib Cinta 85

Pasien Pandemi

Murasaki. .86

Pelangi Muhasabah

Zahrotul Muzdalifah .88

\section{Pemantik}

Rini Damayanti.

\section{Percikan Covid-19}

Kustyarini.

Perjuanganmu

Laily Fitriani 93

Petanda Apa

Abdul Haris. 


\section{Powerless}

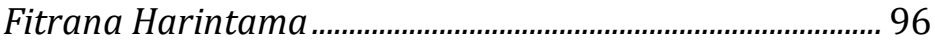

\section{Puisi Pagi}

Elva Yohana

\section{Ramadhan Berjarak}

Novia Dwi Rahmawati

Rasa Itu

Dina Amaliyah Mushthoza

Rendah Hati

Moh. Ali Aziz

\section{Retorika Hati untuk Pandemi}

Tri Kristianti

\section{Rindu}

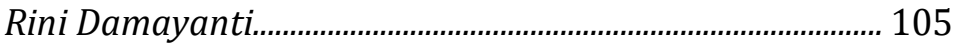

Rumah Laba-laba

Rebbeca Arju

Sajadah Langit

M. Alifudin Ikhsan.

\section{Sajak Rindu}

Harista.

Secercah Berkah di Masa Corona

Yasyir Fahmi Mubaraq

Senjakala Maharajalela

Sony Sukmawan

Sepi Yang Mengerikan

Rizqi Alif Bachtiar 
Seruan Adzan Maghrib

Rebbeca Arju

Sewangi Nabi

Moh.Ali Aziz.

Si Kecil

Afiyah Wardatul Ummah.

Simfoni Rindu

Zahrotul Muzdalifah

Suratan Hikmah Covid 19

Eni Ernawati.

Tak Jadi

Sofwul Widad

\section{Tamu Tak Berhati}

Afif Ikhwanul Muslimin

Tetap Bertegur Sapa

Santri Kalong........................................................................... 134

Titah Fitrah Kita

Winartono

Tolong

Lia Laurence

Tragedi untuk Si/Apa?

Mundi Rahayu

Yang Terasa

Rebbeca Arju

Zonk

Eeng Zur. 


\section{II}

Covid-19 membuat semua orang meradang, akan tetapi di sisi lain menjadi ladang baru untuk meningkatkan hidup jadi

lebih bermutu 


\section{AGAMA DAN MUSIBAH}

'Abd Al Haris Al Muhasibiy*

Setiap saat kami semua ber'doa.

Dengan mengangkat kedua tangan ke atas sana.

Basmalah, hamdalah, salawat dengan penuh puja.

Kerahkan segala tenaga medis dan satgas di.... mana-mana.

Tidak kurang lagi kumpulkan sedekah untuk dana.

Kami semua ucapkan "mata..... nasrullah.......

Kapan pertolongan Allah....datang dan tiba?

Ya ilahi yang penuh puji.

Kami menusia penuh menyadari.

Mungkin selama ini kami lupa diri.

Sangat mengandalkan sains dan teknologi.

Bahkan kami lupa sedikit sekali ilmu yang Engkau beri.

Namun kami sudah angkuh dan sombong sekali.

Seolah-olah kami sudah menguasai langit dan bumi.

Sekarang baru mengerti, hanya dengan virus kecil saja sudah panik sekali.

Ya Allah, meski banyak dosa.

Penuh noda dan bangga meski salah.

Tapi kami tahu Engkau Tuhan Pemurah.

RahmatMu jauh lebih besar dari amarah.

Bahkan Engkau tidak menyuruh kami putus asa.

Justru Engkaulah yang dapat menyika dosa-dosa.

Hilangkan ya Allah.....virus corona dari Indonesia.

Bahkan tarik dari seluruh peredaran di dunia. 
Bukankah Engkau saja yang bisa mengubah.

Musibah menjadi rahmat dan karunia.

Beri kami hidup tenang dengan berwasilah.

Lima kekasihMu, Muhammad Rasulillah.

Sayida Ali Karramallahu wajhah.

Dua anaknya, dan kekasih kita sayidah Fatimah.

*Penulis, Prof. Dr. H. Abdul Haris, M.Ag, adalah Guru Besar/ Rektor Universitas Islam Negeri (UIN) Maulana Malik Ibrahim Malang, Jawa Timur 


\section{APA YANG AKAN TERJADI? \\ Nikmatul Izah*}

Baju tak dicuci

Piring, gelas, peralatan tak dibersihkan

Rumah tak disapu

Mobil tak disedot

Sawah tak disiangi

Gigi tak disikat

Badan tak mandi

Manusia tak mati

Apa yang akan terjadi?

Begitupun pada dunia

Dunia tak dibersihkan

Apa yang terjadi?

Suasana saat ini, corona

Membersihkan dunia dari polusi

Akibat ulah manusia

Tinggallahdirumah

Bekerja

Belajar

Mudik dilarang

Bercerengkama dibubarkan 
Karena memang saatnya kita sejenak

Di rumah

Perlahan..

Polusi udara yang nampak hitam dari atas

Kini terlihat hijau.

Sebenarnya

Begitulah manfaat virus yang diturunkan allah

*Penulis, Nikmatul Izah, M.Pd, adalah dosen di prodi

Teknologi Hasil Perikanan, Fakultas Pertanian, Universitas

Yudharta Pasuruan, Jawa Timur

4 Sastrawan Covid-19 


\title{
APD
}

Laily Fitriani*

\author{
Menatapmu dalam balutan APD \\ Mengusik jiwa terdalamku \\ Nafas terbentuk dalam rasa \\ Kemanusiaan di atas segala
}

Senyummu mendamaikan jiwa

Walau kutahu bebanmu sangat berat

Tidurlah walau sejenak

Melepas kantuk dan penat yang menyerang

Hadirmu turut memberi arti

Membangun empati itu tak mudah

Engkau hadir dan mengetuk hati

Rangkaian semyum kembali menggantung dalam balutan APDmu

*Penulis, Dr. Laily Fitriani, M.Pd, adalah dosen Pascasarjana di Universitas Islam Negeri (UIN) Maulana Malik Ibrahim Malang, Jawa Timur 


\section{ASAKU DALAM KEHENINGAN}

Emi Ermawati*

Tanpa rasa tanpa tanda

Tanpa sebab tanpa akibat

Kalaupun ada kita pun tak tau

Kau tiba-tiba datang

Dan mengubah segalanya

Kini menyebar

Semua orang ketakutan

Seakan tidak peduli dengan ini

Sebagian sadar sebagian pula mengabaikan

Entah sampai kapan

Ini kah cobaan atau peringatan

Ini kah musibah atau kah bencana

Semakin banyak orang lalai saat ini

Karena ini banyak orang yang jadi ingat akan Tuhan Nya

Oh, Corona datang mengubah semua

Memberikan pelajaran bagi kita

Dari yang jauh jadi semakin dekat

Dari yang di abaikan menjadi yang di cari

Engkau mengajarkan arti keluarga

Engkau mengajarkan arti kebersihan

Engkau mengajarkan arti kebersamaan

Engkau mengajarkan arti kesehatan

6 Sastrawan Covid-19 
Oh,... Semua itu hal kecil yang terkadang masih sering terabaikan

Hal sepele namun nampak besar manfaatnya

Hal yang susah di lakukan namun menebar berjuta tujuan

Marhaban Ya Ramadhan

Ramadhan pun datang dengan membawa keberkahan dan rahmat

Namun sayang nya menjadi berbeda dari sebelumnya

Ya Alloh, kapan semua akan berakhir

Angkatlah semua wabah ini

Jauhkanlah balak bencana dari muka bumi ini

Ampunilah dosa-dosa kami

Dengan rahmat dan keberkahan bulan Ramadhan Jadikanlah Ramadhan ini sarana mendekatkan diri kami tanpa ada rasa ketakutan, kepanikan, dan kegelisahan

Harap ku kumintakan dalam setiap doaku Asaku kupinta dalam keheningan malamku

Ya Robbi hanya kepadaMu kami bersujud Hanya kepadaMu kami memohon pertolongan dan ampunan

Dan hanya kepadaMu kami mohon perlindungan

*Penulis, Emi Ermawati, S.S, adalah Pengajar di MA Sunan Kalijogo Kediri, Jawa Timur, dan Owner Anjali Shop 


\section{Bagiku, KORONA itu Kerrong Mekkah Madina, Bagimu? \\ Rahmatillah*}

Ku awali puisiku ini dg Bacaan bismillah... Dan teriring doa pertama kali melihat Ka'bah...

"Allohumma Zid hadal Bait Tasrifan, wa ta'dhiman, wa Takriman wa mahabatan wa Zid man Syarrofahu wa Karromahu min man hajjahu awi'tamarohu Tasyrifan, wa Ta'diman wa takriman wa Birron".

Bagiku, KORONA itu Kerrong Mekkah madina, bagimu? Oh... Mekkah...

Oh... Madina...

Walau dirimu nun jauh dsana...

Tapi trasa dekat dihati hamba...

Muslim sedunia...

Bagiku, KORONA itu kerrong mekkah madinah, bagimu?

Sungguh mnyesakkan dada,

Berlinang air mata,

Kala menatapmu dilayar kaca,

Dan banyak berita..

Bahwa Baitullloh disterilisasi...

Bahwa Raudho juga sepi...

Yaa Alloh jaman apakah ini???

Astagfirulloh hal adhim. Min kulli danbi wa atubu ilaihi.

8 Sastrawan Covid-19 
Bagiku, KORONA itu Kerrong Mekkah madina, Bagimu?

Berurai lagi air mata,

Sesak didada...

Serasa ingin terbang saja kesana...

Ke Mekkah madina...

Kota suci Impian Muslim sedunia...

Mengharap Ridho dan Syafaatnya.

Melepas semua Rindu padaMu Robbi...

Melepas semua Rindu padamu Baginda Nabi...

Tapi...

Sejenak kusadari siapakah Diri ini???

Bekenankah engkau ya robbi... Yaa nabi...

Menerima Hamba dan Ummatmu ini???

Baitulloh... Oh Baitulloh..

Sepi... Sepi sndiri..

Menjadi nuktoh hitam diantara marmer

putih...bersih...berkilau cahaya... Bening... Tapi... Bagaiman

dg dosa dosa hamba ya Robb???

Bagiku, KORONA itu Kerrong Mekkah Madina,bagimu?

Wahai... Wabah yg membawa seribu faedah bagi

kehidupan bumi manusia...

Beginilah akhirnya ku sadari...

Sifat Allihku, tuhanku....

Yg penuh belas kasih..

Rohman rohim..

Pasti ada banyak hikmah dibalik Korona.

Dan kuyakini dalam hati, disepinya malam ini... 
Bahwa suatu saat nnti kita semua kan diundangnya lagi.. Menjadi Duyufurrohman.. Tamu tamu Alloh... Amin.

Karena ternyata Rindu ini smakin mmbuncah saat kita sudah pernah kesana...

Yg belum smoga sgera ditakdirkan menjadi DuyufurrohmanNya juga.

DiundangNya temali cintah KASIHNYA Amin...

Bagiku, KORONA itu Kerrong Mekkah Madina, bagimu? Kututup suara hati ini dg Ucapan hamdalah... Dg iringan doa Tawaf putaran ke Tujuh...

"ALLOHUMMA inni As'aluka imanan kamilan, wa yaqinan shodiqon, wa rizqon wasi'an, wa Qolban Khosyi'an, wa Lisanan Dzakiron, wa halalan toyyiban, wa taubatan nasuhan, wa taubatan Qoblal maut, wa rohatan i'ndal maut, wa magfirotan wa rohmatan bakdal maut, wal afwa i'ndal hisab, wal Fauza bil jannah, wannajati minannar, bi rohmatika yaa Azizu bissholihin amin..

Bagiku, KORONA itu tetap Kerrong Mekkah madina, Entahlah bagimu apa?

*Penulis, Rahmatillah, SS, M.Pd, adalah Pengasuh Yayasan Pondok Pesantren Nurul Hikam Situbondo, Jawa Timur 


\section{BELAJAR DARI COVID-19}

Utami Widiati*

Covid-19, demikian kau bernama

Para pakar berkata, kau berasal dari virus corona

Konon ditengara pertama ada di Cina

Pada Desember 2019 kau mulai terdengar

Bukan sebagai epidemi, ataupun endemi

Tetapi menjelma sebagai pandemi

Dunia secara global terpapar

Kau tak nampak secara kasat

Tapi dampakmu begitu dahsyat

Dari hari ke hari terdengar berita menyayat

Tentang bertambahnya jumlah kehilangan jasad

Covid-19, dalam sekejap kau mengubah dunia

Siapakah sejatinya dirimu?

Entahlah.

Tapi aku tahu Allah berfirman,

"Allah senantiasa mencipta apa yang kamu tidak tahu"

Apakah dirimu adzab atau ujian?

Entahlah.

Tapi aku tahu Allah berfirman,

"Untuk apa Allah menyiksa kamu, kalau kamu

bersyukur dan beriman?" 
Juga

Allah berfirman,

"Sesungguhnya Kami benar-benar akan menguji

kamu agar Kami mengetahui orang-orang yang

berjihad dan bersabar di antara kamu”

Hanya mampu diriku berdo'a,

Yakin hanya do'a yang dapat mengubah qada

Darimu, Covid-19, aku belajar "membaca"

dan semakin percaya perintahNya

iqra'

Meyakini tiada sesuatupun terjadi tanpa

kehendakNya

Agar diriku mampu mengamalkan salah satu penggalan ayatNya

wasjud waqtarib

*Penulis, Prof. Utami Widiati, M.A, Ph.D, adalah Guru Besar dalam bidang TEFL (Pembelajaran Bahasa Inggris sebagai Bahasa Asing), Fakultas Sastra, Universitas Negeri Malang, Jawa Timur. 


\section{BENDERA SYAHID}

M. Alifudin Ikhsan*

Di tengah gemuruh awan menyambut senja

Di keheningan suasana kampus asri penuh cerita

Di ujung bangku kosong bersenandung rasa

Dikala rindu sang pujangga cinta

Tekad bulat membersamai derap langkah bersama

Tak ayal carut pikir ia merasa

Hidupnya penuh gejolak batin berperang seirama

Mencoba tenang mengela nafas

Tidak perlu beradu jika merasa lemas

Semuanya lambat laun akan tuntas

Walaupun tetap bertaruh atas fasilitas terbatas

Aku memberinya semangat untuk terus berjuang Merajut asa merangkai setiap kalimat tuk dikenang Semangat berkobar walau hati menjerit tak senang

Semua tahu bahwa ia sedang berperang

Tapi seolah diam seribu bahasa tuk menceritakan

Mencoba menjaga perasaan segenap orang

Suara rindu ku dengarkan semakin kencang

Bercerita panjang mengenang orang terkenang

Selamat jalan sahabat pejuang

Syahid bersamamu sajadah pemenang

Pandemi ini membuatmu selalu dikenang

Sebagai pahlawan penegak bendera kemenangan 
Aku tetap akan berada disampingmu

Membersamai mimpi mewujudkan cita muliamu Setidaknya ini dharmaku

Yang tak bisa mengantarkan kepergianmu Namun yakinlah kau tetap sahabat terbaik Berharap kita bisa bercengkerama lagi kelak Doaku semoga engkau bahagia di tempat barumu Bendera syahid citamu telah membersamaimu

*Penulis, M. Alifudin Ikhsan, M.Pd, adalah Kepala Sekolah SMP Darul Faqih Indonesiadan Direktur Pesantren Mahasiswa Darul Faqih Malang, Jawa Timur 


\section{BERLALU}

Shohib Cinta*

Di saat Maret berlalu, April datang menjemput rindu...

Di saat corona datang menebar kenestapaan, Ramadan tiba membawa kedamaian...

Aku beriman dengan ayat-ayat-Mu, setiap penyakit ada obat penyembuh...

Aku beriman dengan ayat-ayat-Mu, bersama kesulitan ada kemudahan... Maka aku yakin corona pasti berlalu...

*Penulis, Shohibul Hujjah, S.Sos, adalah CEO Kabarpas Pasuruan (PT. Media Masyah Publika) 


\section{BOCAH DAN RINDU}

Maya Rayungsari*

Bocah kecil menangis

Sang Bapak tak pulang-pulang

Digenggamnya foto Bapak

Peluk erat di dada

Dilukiskan wajah Bapak dalam angan-angan

Nanti malam ia tidur

Sang Bapak musti hadir di mimpi

Akan diceritakan hari-hari yang berlalu

Terkadang benci

Mengapa tak kunjung datang

Ingin seperti dulu

Bermain bersama

Tertidur di pangkuan Bapak

Terkadang resah

Bapak sedang apa sekarang

Penuh tanya tanpa jawab yang mampu ia mengerti

Bapak muda sibuk bekerja di kota seberang

Tak dapat pulang entah sampai kapan

Menggenggam asa, pandemi ini cepatlah berlalu

Kerinduan telah menggunung

Membuncah bersama lamunan di siang bolong

Mata tak menangis

Namun hati selalu teriris

Merindukan intan permata di rumah

Si bocah kecil dengan senyumnya yang manis 
Kelak nanti bertemu

Jika pandemi telah lewat

Akan ditebus semua kerinduan

Dengan cinta yang makin dalam

Kuatkanlah hati

Untuk sementara waktu

Biar hanya bertemu dalam doa

*Penulis, Maya Rayungsari, M.Si, adalah dosen di prodi Pendidikan Matematika, Fakultas Pedagogi dan Psikologi, Universitas PGRI Wiranegara (UNIWARA) Pasuruan, Jawa Timur 


\section{BUKAN NEKAT, TAPI MENDEKAT \\ 'Abd Al Haris Al Muhasibiy*}

Sebagai manusia tetaplah usaha.

Dengan cara gunakan logika sekuatnya.

Memakai rumus dan teori yang sudah terjaga.

Jika perlu dengan strategi yang ganda.

Tetapi tetaplah dengan cara percaya.

Semua yang terjadi tidak pernah di luar desain Allah ta'ala.

Kalau saja corona harus pergi.

Dengan cara ditebas dan ditakut-takuti.

Mungkin dengan seperangkat sabun cuci.

Boleh saja dengan hembusan angin sepoi.

Pendekatan medis dari dalam dan luar negeri.

Pasti kita ikuti dengan cara berhati-hati.

Bukan kita abai terhadap apa yang terjadi.

Namun kita tetap punya formula yang lebih.

Dengan khataman, istighatsah dan salawat Nabi.

Zikir yang kita baca setiap hari.

Bermakna bahkan bisa meneguhkan hati.

Bahwa yang terjadi tidak pernah lepas dari takdir ilahi.

Bukan untuk membela diri untuk hara hiri.

Bukan pula siap menantang dan menyalahi.

Justru dengan corona menjadi peringatan manusia di bumi. Jangan sok jagoan dan sok paling baik sendiri. 
Mari cegah corona dengan tinggalkan maksiat.

Tetap beraktivitas bukan nekat, tapi upaya mendekat.

Supaya corona tidak semakin rekat kita jadi selamat.

*Penulis, Prof. Dr. H. Abdul Haris, M.Ag, adalah Guru Besar/ Rektor Universitas Islam Negeri (UIN) Maulana Malik Ibrahim Malang, Jawa Timur 


\section{CELOTEH HATI BISU}

Ilmie*

$\mathrm{Bu}$, pakemake

Apa nak?

$\mathrm{Bu}$, pakemake

Ada colona

(Ohh pakai masker)

Ungkap seorang anak kecil yang mungil kepada Sang

Bunda

Begitu tenar kau corona, hingga anak sebelia itu mampu melantunkan namamu.

Sayang kesahduan lantunan yang terucap dari bibir mungil tak seindah kenyataan yang melanda dunia saat ini.

Yah....kau sang corona covid-19.

Kau mendunia yang mampu menaklukan seluruh jagad raya. Seruan bisu rakyat jelata menggema tanpa bersuara. Ringkihan hati menangis dan meminta....kau untuk pergi selama lamanya.

*Penulis, Ilmiyatur Rosidah, M.Pd, adalah dosen di prodi Pendidikan Bahasa dan Sastra Indonesia, Fakultas Pedagogi dan Psikologi, Universitas PGRI Wiranegara (UNIWARA) Pasuruan, Jawa Timur 


\section{CINTA TEGAR DI TENGAH CORONA}

Jenny Lukito Setiawan*

Sayang,

telah banyak korban akibat Corona

akankah cinta kita salah satunya?

Sayang,

telah banyak impian kandas karena Corona

haruskah cinta kita juga kandas karenanya?

TIDAK!

Hai engkau Corona

jangan coba porandakan cinta kami

Hai engkau Corona

jangan coba ceraikan kami

Sayang,

Corona adalah ujian bagi kita

Ia boleh menerpa hidup kita

namun jangan biarkan ia merenggut cinta suci kita

Sayang,

Kita buktikan cinta sejati kita

Kita pegang janji setia kita

Kita hadapi bersama musuh kita 
Sayang,

Terkurung lama di rumah

membuat ujaranku tak semena

Rasa cemas dan gelisah

membuatmu terluka oleh lakuku

Sayang,

Jika tutur kataku menyakitimu

katakan padaku

Jika tingkah lakuku melukaimu

ungkapkan padaku

Sayang,

Kita tenangkan

gejolak jiwa kita

Kita cari cara

agar cinta kita terus bertumbuh

Bertumbuh ...

berkembang ...

mengatasi kemelut Corona

sampai maut pisahkan kita

(Puisi ditulis untuk mengingatkan suami dan istri agar terus menjaga relasi penikahan mereka di tengah badai Corona.)

*Penulis, Prof. Dra. Jenny Lukito Setiawan, M.A., Ph.D., adalah Guru Besar dan psikologprofesional yang mengajar di Fakultas Psikologi Universitas Ciputra Surabaya, Jawa

22 Sastrawan Covid-19 
Timur. Penulis juga merupakan Founder Universitas Ciputra Marriage and Family Centeryang menjadi pusat kajian pernikahan dan keluarga untuk mencapai keluarga Indonesia yang tangguh dan sejahtera.) 


\section{CORONA}

Choirul Rozi*

Sejak wuhan umumkan wabah melanda Ketika itu negara lain merana Karena para ahli bisa menerka Menular kemana mana semua negara Tak ada yang mengira Kisah dramatis korban corona mendera Berjatuhan dimana mana

Dunia maya pun jadi acuan penghantar berita Karena kita harus dirumah saja

Sebagian kita tak kerja Sebab kantor dan toko toko tidak buka Sampai waktu tidak terbatas Tentu ini tidak biasa Ada yang bisa makan esoknya ada yang sama sekali tidak bisa makan

Dilain hal, para ahli menilai Karena murni penyakit menular diri

Karena pertarungan ekonomi antar negara tiada henti Karena adanya depopulasi Karena muncul tanda zaman ahir Bahkan karena konsipirasi 
Entah bagaimana kelanjutannya

Ikuti prosedur yang ada

Hanya pasrah kepada Maha Kuasa

Melantunkan ayat AlQuran

Pada puasa penuh kuasa

*Penulis, Choirul Rozi, SS, M.Pd, adalah dosen di Jurusan Bahasa dan Sastra Inggris, Fakultas Humaniora dan Budaya, UIN Maulana Malik Ibrahim Malang, Jawa Timur 


\section{CORONA, SI KUYANG DAN SINAR ROSUL}

Rebbeca Arju*

Kau lebih dari kuyang...

Tanpa bertubuh, melayang-layang

Bahkan, kau sungguh garang mencabik nadi setiap orang....

Janin di kandungan pun, kau buat goncang

Hingga semua tampak sangat gamblang,

Kau memaksa kami untuk perlahan berpetualang.

Mengejarmutak pedulikanparang yang menghadang.

Namun,

Bukan darah yang kau tuju

Tanpa gejala kau mampu membunuh

Cukuplah bagimu sedetik membuat kaku

Sekujur tubuh, membeku

Hingga saat ini...

Wacana kerdil pun penuh mengharu biru

Kau biarkan kami berkeluh

Sedang engkau tersenyum malu

Karena kami lupa atas titah penciptaanmu

Liiilaa fi quraisy, kasihku tak lumpuh panik.

Iila fihim rihalatasyifaa'i wasshoif, karena kau bukanlah soal otak mantik.

Fal ya'buduu robba hadzal bayt, tapi kau jawaban dan solusi tercantik.

Cukup dan cukup-kala Rosul melihatmu membaik, corona pasti akan pamit balik.

26 Sastrawan Covid-19 
Tentu kita tak kan sanggup berpisah,

Tentu kita hanya suka tertawa,

Tentu akan berat menahan derita,

Walau sarwa dan rasa hanyalah panorama.

*Penulis, Barotun Mabaroh, SS, M.Pd, adalah dosen di prodi Pendidikan Bahasa Inggris, Fakultas Pedagogi dan

Psikologi, Universitas PGRI Wiranegara (UNIWARA)

Pasuruan, Jawa Timur 


\section{C-SEMBILAN BELAS}

Supra*

Tidak terlihat tapi nyata

Lemah tapi memporak porandakan

Tidak nyata tapi smua terpana

Senyap tapi menggetarkan

Badai pasti berlalu

Badai pasti berlalu?

Yakin, badai pasti berlalu

Bersama badai ada harapan baru.

Sambut harapan dengan hidup bersih dan peduli

Harapan baru dengan prilaku terpuji dan rendah hati

Nyatakan dalam syukur dan hidup teratur

Lakukan dengan selalu ingat dan tafakur.

*Penulis, Dr. H. Sugeng Pradikto, M.Pd, adalah Rektor Universitas PGRI Wiranegara (UNIWARA) Pasuruan, Jawa Timur 


\section{DIAM}

Maria Ulfa*

Diam diam kau datang beriringan
Diam diam kau menjamah kedamaian
Diam diam kau merusak kenyamanan
Diam diam kau hancurkan perekonomian
Diam diam kau robohkan kebersamaan
Diam diam kau mencoba memberi peringatan
Diam diam kau tunjukkan arti kebersamaan
Diam diam kau tunjukkan arti keluarga dalam pelukan

Diam untuk selamat

Diam untuk tetap berhemat

Diam untuk memutus akibat

Diam demi mereka yang terhormat

Diamku untuk melakukan yang bermanfaat

Diamku di ribuan langkah yang cepat

Diamku merenungi akibat merasa hebat

Diamku berlari dari segala dosa maksiat

Diamku mencari apa sebab apa akibat

Diamku menyadarkanku dari berdebat

Diamku mengajarkanku untuk tetap semangat

*Penulis, Maria Ulfa, S.Pd, adalah guru di Madrasah Ibtidaiyah (MI) Darul Ulum, Kota Batu Jawa Timur 


\section{DILEMA PANDEMI}

Maya rayungsari*

Pagi ini aku terdiam di teras rumah

Tanpa baju kerja

Tak pergi bekerja

Tempat kerjaku pailit kena pandemi

Aku diputus kerja

Begitu saja

Aku tercenung
Padahal kukira
Kita keluarga
Padahal kurasa
Di sanalah rumah keduaku
Nyatanya aku hanyalah pion

Beginilah jadinya

bergantung pada manusia

berakhir kecewa

Pagi ini kupandangi wajah istri dan anakku Bagaimana lantas mereka bisa makan Bagaimana bisa menyambung hidup

Bagaimana bisa bertahan

Bagaimana bisa...

Kubenamkan hati dalam kelabu 
Lalu

Secercah sintar matahari

Membuatku tersentak

Membuatku malu

Mengapa aku

Merasa paling malang di dunia

Ini tak seberapa

Derita ini tiada arti

Jika aku pikirkan lagi

Seumur hidupku

Nikmat yang aku rasakan

Segala yang telah kuterima

Telah jauh melebihi

Apa yang aku butuhkan

Sungguh malu

Kini ku kan bangkit

Ku yakin pertolongan kan datang

Jika aku tak putus asa

Jika usaha ini tak kenal padam

Lalu tiap malam,

Kan kugantungkan asaku

Hanya pada Rabbku semata

*Penulis, Maya Rayungsari, M.Si, adalah dosen di prodi Pendidikan Matematika, Fakultas Pedagogi dan Psikologi, Universitas PGRI Wiranegara (UNIWARA) Pasuruan, Jawa Timur 


\section{DOA PALING MUSTAJAB}

Fitri Kharisma Putri*

Rindunya pecah,

dikeheningan malam yang sendu

jatuh tenggelam dalam sujud nan pilu

selepas ia panjatkan alunan doa yang menderu-deru

—ia terisak

Larut dalam sunyi yang sungguh maha rahasia

sebab, kala ramadan datang menyapa

ada yang tak ikut pulang bersamanya

bagai ironi dan petaka meski ia terus terisak dalam

hampa

-abadi

Kata nona, ramadan kemarin tak pernah seseram ini Jalanan panjang di sudut kotanya sepi, bagai kota mati Semua orang lari terbirit-birit kala hari mulai petang—dan, sebuah fatwa mulai menghantui:

"lebaran tahun ini jangan mudik dulu!

Takut nanti malah menyebar resah di kampung halaman"

Maka, didatanginya seorang ahli nujum paling lantang di kotanya-adalah mereka yang pandai melafazkan doadoa paling mustajab dalam sujud di seperdua malam yang agung 
dan ia mulai menarik napas panjang,

kemudian meraba-raba secarik kertas kosong

-ada asa di sana;

“Akan kuamini kepergianmu!

esok lusa, negeriku harus kembali sehat seperti sedia-kala :karena, ramadan kali ini ada rindu yang harus sampai pada tuannya dan, pulang adalah jawaban dari doa-doa paling mustajab ini, bukan?"

*Penulis, Fitri Kharisma Putri, SS, adalah alumni S1 (Sarjana Sastra) Universitas Muhammadiyah Gorontalo. 


\section{DUNIA DALAM DUKA}

Ani Fiani*

Wahai...

Dunia yang mempesona, Anugerah sang Pencipta.

Awalnya, kami semua hidup dengan penuh suka cita, Tertawa bahagia penuh canda, Berkumpul dalam berbagai acara, Beraktifitas tanpa ada rasa gundah, Bebas tanpa batas ke mana pun kaki melangkah.

Dunia yang begitu indah bak syurga,

Telah membuat banyak manusia terlena, Membusungkan dada, Seakan bisa melakukan segalanya, lupa dengan batasan yang ada, Sehingga membuat dunia terlilit kabut duka.

Sekarang,

Dunia ini malang,

Dunia ini terkekang,

Dunia ini terguncang.

Keegoisan sebagian orang membuat dunia ini merana, Keangkuhan membuat dunia ini sengsara, Kecerobohan membuat dunia ini menitikkan air mata. 
Mungkin...

Sang Pencipta telah bosan,

Banyak peringatan dilupakan,

Banyak aturan tak diindahkan,

Banyak kewajiban telah diabaikan,

Sehingga Corona pun didatangkan.

Corona...

Makhluk kecil tak kasat mata,

Lebih halus dari sutra,

Lebih kuat dari baja,

Lebih buas dari srigala,

Lebih kejam dari penguasa.

Corona,

Si mungil yang mendunia,

Datang lalu berkelana sesuka hatinya,

Tak pandang miskin ataupun kaya,

Balita ataupun lansia,

Rakyat biasa ataupun pejabat negara

Semua tak luput dari cengkramannya.

Corona...

Dunia ini sekarang mencekam,

Dunia ini sekarang menyeramkan.

Corona...

banyak orang menangis darah,

Tak bisa bekerja dan beribadah seyogyanya, 
Terpaksa menahan lapar dan dahaga,

Bahkan harus rela kehilangan sanak saudara.

Ooh Tuhan...

Ampuni kami yang telah lalai,

Ampuni kami yang telah terbuai,

Dengan Izin-Mu, Corona pergi,

Dengan Izin-Mu, dunia ini kembali berseri.

*Penulis, Ani Fiani, SS, M.Pd, adalah dosen di prodi Pendidikan Bahasa Ingrris, STKIP-PGRI Lubuklinggau, Sumatera Selatan. 


\section{EMPAT KISAH SELEPAS ZIARAH}

Sakban Rosidi*

\section{Kisah 1, Leviathan}

*Selepas ziarah pasca pandemi

Berjuta rakyat jatuh melarat

Tiada pembela, putus saudara

Tinggal negara punya kuasa*

Tinggal penguasa berharta-benda

Berjuta hamba-sahaya mengemis negara

Berjuta jelata-sudra menghamba penguasa

\section{Kisah 2, Homo Homini Lupus}

*Selepas ziarah pasca pandemi

Negara-bangsa tiada berdaya

Tanpa kuasa, tiada berharta

Tinggal manusia tajam naluri*

Tinggal manusia tumpul nurani

Berpuluh ribu binatang memangsa sesama

Berpuluh juta binatang dimangsa sesama

\section{Kisah 3, Utophia}

Selepas ziarah pasca pandemi

Berjuta rakyat menjadi bangkrut

Bertahan hidup harus menurut

Tinggal negara boleh berkuasa

Tinggal penguasa boleh berharta

Kami berjanji sama rata, sama rasa

Kita bermimpi sama rata, sama rasa 


\section{Kisah 4, Homo Homini Socius}

Selepas ziarah pasca pandemi

Negara-bangsa menjadi bangkrut

Tiada kuasa, hanya menurut

Kami pun musti berdayabudi

Kita niscaya berbudidaya

Cedera luka masa pandemi, memanggil para pemimpin

Perih hidup masa pandemi, melahirkan para pemimpi

*Penulis, Dr. KH. Sakban Rosidi, M.Si, adalah Direktur Pascasarjana, IKIP Budi Utomo, Malang, Jawa Timur. 


\section{GEMURUH}

Rebbeca Arju

Suara gemuruh terdengar dari langit

Riuh beradu, bak pertengkaran sengit

Tapi dua telingaku tak peka walau secuit

Meski hati meronta, menguping tiap dekrit

Kini semua telah sangat jelas

Gembar gembornya pun sangat keras

Bumi dibakar oleh silsilah korona ganas

Yang telah memangkas iman seutas

Korona, si imut-pusat makian sejagat raya.

Tuhan pun bersaksi bahwa sungguh manusia adalah ciptaan terbaik.

Korona, si molek-muara kebencian semesta.

Tuhan juga bersaksi bahwa manusia tetaplah yang terbaik.

Korona, si manis-identik dengan rayuan kematian.

Dan Tuhan kukuh bersaksi manusialah satusatunyamakhluq yang terbaik.

Mungkin karena ini, akumerasapaling akrab denganNya. Mungkin juga karena itu, aku rasa bisa menegoNya.

Atau mungkin, tak ada iman siagaku kepadatakdirburuk?

Berlagak alim melebihi nabi dalam menyikapi pandemi.

Bergayasantuy bahwa semua pasti akan mati.

Bahkan mewacana bahwa korona hanya gerakan aliansi. Hingga akhirnya, kusaksikan sendiri 
Korona membidik dan menjangkiti

Orang-orang sekitar agar menjadi bukti

Mereka telah menyendiri dalam sepetak bumi-tak disholati

Masihkah aku pengkoh dengan ego sendiri?

Oh Korona,

Dikau sungguh membuatku insomnia

Kau menutup malamku dengan hari yang baru

Dan membuka hariku dengan dengan nurani yang lesu

Kau bahkan membelenggu leher lemahku

Dan kau ingin mempercepat setiap misal

Meski tak tentu semua mendapati ajal

Korona,

Kasihku melepasmu sebagai halilintar

Menyambar tuk menguji siapa yang sabar dan sicupar

Kau bahkan tak peduli hadirnya sang Badar

Meski ia meleraimu dariku yang sudah gusar.

Kau datang, tanpa ku sadari

Mengurangi penduduk bumi dari setiap tepi

Kala ku terbangun nanti,

Tanpa penolakan, ku mohon kau undur diri

*Penulis, Barotun Mabaroh, SS, M.Pd, adalah dosen di prodi Pendidikan Bahasa Inggris, Fakultas Pedagogi dan Psikologi, Universitas PGRI Wiranegara (UNIWARA) Pasuruan, Jawa Timur. 


\section{GUGUR BUNGA}

Bintang Soraya*

Lagu gugur bunga sekarang menggema

Banyak dari mereka merasa gemetar

Melihat lebih dari peleton - peleton berjuang

Tapi mereka hanya dipandang sekadar manusia di bidang kesehatan belaka

Lagu gugur bunga sekarang kembali lantang bersuara Banyak dari mereka menangis Melihat dari peleton - peleton menempati garuda terdepan Tak pulang, tak istirahat, tak putus asa

Sekarang lagu gugur bunga mulai meraja di rumah - rumah Menangis mereka - reka mengharap asa mereka menang Walau tak tahu sampai kapan mereka tak mendapat sepenuhnya dukungan

Para masyarakat dungu yang bersorak

Dan setiap hari lagu gugur bunga berkumandang Yang menandakan banyak pejuang yang gugur dalam perang

*Penulis, Bintang Soraya, adalah mahasiswa di prodi Pendidikan Bahasa Inggris, Fakultas Pedagogi dan Psikologi, Universitas PGRI Wiranegara (UNIWARA) Pasuruan, Jawa Timur. 


\section{HILANGLAH}

Any Ikawati*

Hilanglah...

Pandemimu mematikan

Partikelmu banyak merenguk nyawa

Kau menyengsarakan makhluk berjiwa

Kau, mahkota, berkelana kemana-mana

Hinggap dan bertaburan di udara

Berbahaya, menetap di zona lemah

Corona hilanglah...

Kecilmu...

Menyeramkan sekaligus mematikan

Dunia menjadi asing saat kau datang

Penghuni bumi resah berusaha menantang

Oh Tuhan lindungilah

Kuatkanlahkami-manusia

Orang tua, anak-anak,

Muda, manula,

Tanpa pandang bulu

Karena jika semua lemah, maka hancurlah dunia ini

Tuhan..

Kita hanya bisa berdoa

Kita hanya bisa berusaha sehat

Menggairahkan semangat

42 Sastrawan Covid-19 
Agar antibodi semakin kuat

Ku yakini kata-kata adalah doa

Corona hilanglah dari muka bumi ini

Corona hilanglah

Hilanglah

*Penulis, Any Ikawati, M.Pd, adalah dosen di Fakultas

Keguruan dan Ilmu Pendidkan, Universitas Wisnuwardhana, Malang-Jawa Timur 


\title{
Hitamnya SentilanMU
}

Eko Pujiati*

\begin{abstract}
Akhir tahun dua ribu Sembilan belas terbersit suatu harapan yang indah Jalannya kehidupan berharap menjadi lebih baik dari yang lalu
\end{abstract}

Terbayang sudah untuk meniti jalan hidup berubah Bagai mimpi yang mampu memberi warna yang biru Berawal dari negeri China suatu virus mewabah Merebak diberbagi negeri lainnya seperti debu Seolah kecepatan melebihi Jembatan Shirathalmustaqim... hei wabah

Kehidupan dunia terasa terbelenggu

Semua jalan kau buat menakutkan hati ini... hai pademi Ya Allah berilah cahaya untuk menerangi

Pademi membuat nalar tidak berfungsi

Ketakutan mulai mengikis hati padaMU Illahi

Rumah ibadah berhenti menjadi sunyi

Dicoba untuk merenungi.....

Januari seolah memberi bentangan indahnya hari

Februari awalnya sentilan Illahi ....

Hari demi hari semakin sunyi sepi ya Rabbi yang Maha Besar

Kegelisahan tidaklah lekas pergi

Sampai lah sekarang di hari suci kita coba bersabar dan terus bersabar

Pandemi ini mari kita renungi sebagai ujian nyali Bak tercebur kumbangan yang dalam dan lebar

44 Sastrawan Covid-19 
Nyanyian indah di bulan Suci menebar hari tuk berseri Membawa kita sejenak terhindar .....

Satu Syawal sebagai hari yang kita nanti perginya hei pademi.....

*Penulis, Dra. Eko Pujiati, S.H., M.Pd, adalah dosen dan sekaligus menajabat dekan Fakultas Keguruan dan Ilmu Pendidikan, Universitas Wisnuwardhana Malang, Jawa Timur 


\section{HITUNG SENDIRI}

Rebbeca Arju*

Banyak negara baru memulai tahap awal pertarungan

Meski sejak 19 Desember 2019, mendengar kegaduhan di Wuhan

Tedros bahkan yakin bahwa virus ini akan bersama kita untuk waktu yang lama Untuk apa?

Tak terkendali, Tak terhenti, OUTBREAK!!!!

Beralih Mei....

Tercatat 3.090.445kasus terkini

10.118terjadi di bumi pertiwi

217.769penduduk dunia telah mati

Indonesia mengkubur 792 peti

Tapi... dengan mantap kau berdeklarasi

Angka itu belum sesuai misi!!!!!

Dan kau yakinkan gelombang kedua wabah itu pasti.

Oh harga diri,

tak mampukah kau hitung cukup dengan jemari?

Bukan dengan digit gengsimu yang membumbung tinggi

Tak cukupkah kau diaku yang paling menguasai?

Hingga nyawa hanyalah bagian dari seni.

Brakkk... kau gampar meja kerjaku

Rupanya kau tahu aku sedang menggerutu,

Tanda tak setuju dengan ketetapanmu.

46 Sastrawan Covid-19 
Tiap hari aku melaporkan tangis dan duka semesta padamu.

Kau puas, kini dunia dalam genggamanmu

Vaksinmu ramai laku, karena propaganda dahsyatdarimu.

Tapi aku ibah padamu

Tak sedikitpun cinta ada pada rohmu

Tak secuilpun empati ada di nuranimu

Andai kau tumbuh sepertiku,

Orang tua adalah segalanya bagiku

Tak sepertimu yang menganggap mereka pelaku insiden biologis

Yang memaksamu terlahir, tumbuh, berkuasa, digdaya, tapi bengis.

Teman adalah penopangku

Kita saling berkejar-kejaran kala kecil,

Tak sungkan untuk makan gembul

Menangis dan terbahak bahkan untuk hal makzul.

Surau kami, tempat mengaji

Mengadu banyak hal tentang pelajaran dan budi

Pada guru kami yang tak digaji

Namun sungguh mulia pekerti.

Aku rindu mereka, tapi ku terkunci

Hanya karenaambisimu,

Gerilyamu,

Dajjalmu. 
Brakkk... kau gampar mejaku sekali lagi.

Aku tetap diam,

Ku saksikan kau menjerit berteriak seperti biasanya

Ku yakin itu adalah rintihan jiwamu yang rindu cinta kasih

Yang sangat sulit kau peroleh walau dengan uang dan

teknologi.

Ku beranikan diri menatap matamu,

Berharap ketulusan menghampiri

Tapi sayang, otakmu tetap penuh angka-angka

Hitungan itu kau sembah laksana dewa-dewa

Kau perintahkan bonekamu beroperasi di area yang belum terpapar sempurna.

Aku tak kuasa,

Tak ada..

Tak sanggup lagi berharap seberkas lentera di jiwamu.

Hitunglah sendiri kepuasanmu,

dan biarlah ku mati dengan jati diri.

${ }^{*}$ Penulis, Barotun Mabaroh, SS, M.Pd, adalah dosen di prodi Pendidikan Bahasa Inggris, Fakultas Pedagogi dan Psikologi, Universitas PGRI Wiranegara (UNIWARA) Pasuruan, Jawa Timur. 


\section{IKATAN KITA DAN CORONA}

Leny Yuliati*

Dunia terhentak oleh molekul virus

yang makna namanya indah yakni mahkota namun penuh duri dan meracuni dalam senyap.

Struktur kristalnya dipelajari dengan teknik canggih nan bagus interaksi dan kinetikanya dieksplorasi dengan detil dan tertata bahkan kandidat molekul inhibitornya diprediksikan dengan mantap.

Ketika interaksi terjelma antara virus Corona dan sel manusia ikatannya begitu stabil dan tak mudah dilepaskan namun bukan berarti tak bisa dicegah dan tak bisa diputuskan

ikatan itu bisa dicegah dengan menciptakan vaksin pendorong antibodi

dan bisa diputuskan bila molekul virus berjumpa dengan inhibitor proteasenya ini perlu usaha, waktu, dan dukungan semuanya untuk mendapatkannya.

Dimanakah kita ...

ketika para pakar berjuang mencari jawaban agar virus dapat dikalahkan ketika para medis berdiri di lini depan tanpa ragu-ragu untuk menyelamatkan ketika hanya 
diminta di rumah saja dan membatasi interaksi sebagai wujud peduli dan mengabdi

setidaknya jangan mengikat diri dan membatasi hati untuk selalu mengirimkan doa agar ikatan kita dan Corona bisa segera dihapuskan dan interaksi antar manusia dipulihkan.

Teriring salam dan ucapan terima kasih tak terhingga kepada para pejuang dan pahlawan Corona.

*Penulis, Dr.Eng. Leny Yuliati, S.Si., M.Eng. adalah dosen yang mengajar di program studi Kimia, Fakultas Sains dan Teknologi, Universitas Ma Chung. Penulis juga merupakan Peneliti Utama di Ma Chung Research Center for Photosynthetic Pigments. 


\section{KAMI TAK BERDAYA}

Zaidatun Elif*

Aku hanya buruh harian

Aku hanya pedagang mainan

Aku hanya pedagang makanan ringan

Aku hanya pedagang depan lembaga pendidikan

Kami hanya butuh sesuap nasi

Bukan untuk bermewah diri

Apalagi untuk membanggakan diri

Karena itu jauh dari mimpi nyata kami

Namun, kini kami harus berdiam diri

Karena kegiatan kami selalu diawasi

Kami dianggap sebagai penerbar pandemi

Kerumah Tuhanpun kami dibatasi

Kami sempat berfikir dalam diri

Kami diam dirumah, kami akan mati

Karena rasa lapar yang menimpa diri

Keluar rumah, kami juga dihantui mati

Waswas terjangkit wabah pandemi.

*Penulis, Zaidatun Elif, S.Pd, adalah guru di MI Tsamrotul Afkar, Pasuruan, Jawa Timur. 


\section{KAU RONA}

\section{Murasaki*}

Kau rona pancarkan bias keteduhan

Seragam putih bersih melekat di tubuh tersirat segala ketulusan

Di dalam pandemi yang berkepanjangan

Kau rona yang mampu menghapus kepanikan

Memberi kami rasa aman dengan semua wawasan

Tentang himbauan dan larangan kesehatan

Menghampiri kami meski tak kaukenal

Merangkul kami tanpa rasa sungkan

Kaki melangkah cepat, tangan meracik obat

Tak kauhiraukan wajah putihmu pucat memendam penat

Senyum tertutup oleh kain masker yang terikat

Namun tetap terdengar jelas di antara suaramu yang penuh semangat

Di dalam pandemi covid 19

Kami yang tertapapar merasa sesak napas

Kau rona Sang pejuang kami yang tegas

Tanpa ragu menjaga dan merawat kami tanpa batas

Kami yang sehat mengunci diri dalam sepi

Kami yang sakit merintih dalam ruang isolasi

Kau rona tetap terjaga di antara hati yang terkunci

Menahan rindu dan kasih sejati

Menolak pelukan dari keluarga sendiri

52 Sastrawan Covid-19 
Memenjarakan ego pribadi demi satu tugas mulia ini Air mata tak lagi datang ketika menangis

Keringat bukan lagi simbol penat

Lapar dan dahaga mampu kautepis

Di tengah pandemi virus corona, kau rona penyemangat

Sehatlah bumiku

Istirahatlah para medisku

Terima kasih kami untukmu para medis yang selalu ikhlas dan optimis

Doa kami pada Tuhan agar memberimu pelangi seusai gerimis

*Penulis, Sugianti, M.Pd, adalah dosen di prodi Pendidikan Bahasa dan Sastra Indonesia, Fakultas Pedagogi dan Psikologi, Universitas PGRI Wiranegara (UNIWARA) Pasuruan, Jawa Timur 


\section{KIANA BERKELANA \\ Dina Amaliyah Mushthoza*}

Dua ribu dua puluh

Tergempar sejarah tentangmu

Dari ujung Artik hingga Antartika

Tergoncang seratus delapan puluh derajat putarannya

Dari Asia kau mulai menyerang

Berlayar, berlabuh di Eropa dengan senang

Berkeliling mengudara ke Amerika

Singgah di Afrika dan Autralia juga

Sungguh lembut dirimu menyapa

Menapaki jutaan ribu nyawa

Jiwa raga tertusuk halus

Tujuan tak berjalan mulus

Dunia menjadi berbeda

Terpikir puncak sakitnya alam semesta

Menganggap bumi sedang rusak

Asal mula pandemi dalam benak

Diam, berkaca adalah solusi

Diri masih penuh dengan misteri

Kemurnian sering melayang-layang

Kekhilafan kerap kali lalu lalang 
Akankah kau ingin tetap berkelana?

Sudahlah, akhiri saja

Penyerbuan peluru-peluru gubahan

Segeralah membuatmu terhempaskan

*Penulis, Dina Amaliyah Mushthoza, M.Pd, adalah dosen di Universitas Qomaruddin Gresik, Jawa Timur 


\section{KISAH PERJUANGAN DUA SEJOLI}

'Abd Al Haris Al Muhasibiy*

Langit mendung, malam sepi.

Tiba-tiba pesan muncul di hp mahasiswi.

Pesan yang tidak biasa, terasa sangat pedih.

Bahkan seperti tinggalkan pesan yang misteri.

"Maaf dinda, mungkin kita tidak akan bertemu lagi."

"Dinda tidak perlu bertanya mengapa ini terjadi"

Mahasiswi terus membalas pesan berkali-kali.

Namun sekali pun tidak dibalas sampai hari menjelang pagi.

Ternyata dua insan sepasang kekasih.

Menjalin kasih dengan penuh setia dan sumpah sampai mati.

Meski sudah mengikat kata dan mengikat janji.

Dua sejoli tetap bergaul dan menjaga secara syari.

Kecuali dengan media yang tidak timbulkan syahwat manusiawi.

Hari Senin pagi mahasiswi bertanya kepada teman kekasih.

Sesama kos di sebuah rumah di dekat kali.

Ternyata teman tidak tahu kemana kekasih pergi.

Tidak cukup bertanya, mahasiswi menyelidiki.

Sampai ke rumah keluarga yang sangat jauh sekali.

Cinta membara berbalut luka ternyata sang kekasih telah mati.

56 Sastrawan Covid-19 
Keluarga pun tidak tahu, mengapa semua bisa terjadi.

Terkejut peristiwa telah memukul keluarga tanpa henti.

Sang kekasih meninggal tanpa diketahui.

Kekasih merana dan tinggalkan kesan di lubuk hati.

Hati berduka bertambat lara cinta memang tak abadi.

Ternyata sang kekasih tertular corona.

Meski sudah berusaha dengan sekuat tenaga.

Bahkan kekasih cukup kuat menjaga diri dan keluarga.

Tapi takdir Allah datang kepadanya juga.

Sambil terisak, mahasiswi ucapkan kata cinta.

"Wahai kekasih, engkau telah pegi kepada Sang Pemula"

"Meski engkau telah tiada, cintaku takan pernah punah"

"Engkaulah, kekasihku selama-lamanya...."

Sambil mengusap air mata di pipinya, lalu berkata.

"Wahai Corona, Engkau telah pisahkan aku dan

kekasihku....kusimpan duka"

Mahasiswi pergi dan datangi perhelatan istighatsah.

Ia niatkan berdoa dan mengobati perih luka.

Hanya Allah semata yang bisa matikan makhluk manusia.

Inilah Cinta kekasih terhalang wabah corona.

*Penulis, Prof. Dr. H. Abdul Haris, M.Ag, adalah Guru Besar/ Rektor Universitas Islam Negeri (UIN) Maulana Malik Ibrahim Malang, Jawa Timur. 


\section{KORONA,AKU TAK TAHU}

Halimi Zuhdy*

aku tak tahu,

kapan angin menyapaku

kapan ia merayuku

kapan pula menghempaskanku

aku tak tahu,

berapa angka yang menyusup, menelusup

kapan pula menjarah paru-paru, jantung

kadang ia membuat main tenggorokan, dihimpit nafas menyempit, dahak berdarah

tiba-tiba ia tak lagi bersemanyam dalam tubuh, kabur!

mencari kubur

Aku juga tak tahu,

angin mana yang membawa cinta

angin mana yang menghantar corona

tiba-tiba ia sudah membawa kabar duka

$\mathrm{Ah}$,

kadang aku tak pernah mengerti

mengapa ia hadir begitu ngeri

bukan aku takut,

kehadiran dan kepergiannya penuh misteri

58 Sastrawan Covid-19 
Ia bukan kabut, bukan mayonet, bukan pula gerombolan monyet, atau tentara membawa teng dengan ribuat granat

Ia laksana musuh dalam selimut, berkelit, menembus, menikam, orang pada tiduran

Bukan aku menantang, Ia tiba-tiba datang, menyapa sesiapa yang menghindar, diam, apalagi beramai-ramai

Nafasku angin, aku dipaksa menutup mulut dan hidung. Aku pun bermasker.

Nafasku angin.

Aku dipaksa menutup pintu. ia lewat jendela.

Aku tutup pintu jendela, ia lewat celah tembok rumahku.

Aku tutup, pintu, jendela, celah tembok, genting, ia lewat makhluq gepeng di tanganku...ngeri

kalau aku tutup semua,Terus aku bernafas pakai apa?

Aku disuruh menjauh dari tempat ibadah, Aku ma'lumi, ibadahku tak mengenal tempat Aku dihalau dari keramaian, pasar, mal, warung, kantor, kampus, 
aku juga ma'lumi,

hidupku tak butuh ramai, aku butuh damai.

Aku tak tahu

Aku disuruh berkhulwat di rumah.

Rumahku tak pernah sepi, bagaimana aku menyepi

Bila aku keluar mencari nafas perutku

Katanya egois,

aku membawa angin pandemi

Terus...bagaimana aku menyambung nafasku

Korona,

Kau tak pernah bersabda, tapi seribu bahasa sudah kau cipta

kau tak pernah berkhutbah

tapi jutaan nasehat kini mewabah

Aku tak pernah tahu, kapan kau pergi, datangnya tak pernah izin padaku

kini aku tahu, semakin tahu

Aku hanyalah nafas dari angin rindu

pada akhirnya,

aku harus berkhulwat di gua khira'mu, entah karena takut atau iman yang menggebu

Ini pertaruhan imanku.

Hanya kau yang tahu.

60 Sastrawan Covid-19 
*Penulis, Dr. KH. Halimy Zuhdy, M.Pd, M.A, adalah dosen di Universitas Islam Negeri (UIN) Maulana Malik Ibrahim Malang, Jawa Timur 


\section{KUN FAYAKUUN \\ Mohammad Adnan Latief*}

Masihkah kita remehkan

Menyombongkan diri dari bahaya mematikan

Covid19?

Di awal mewabahnya, banyak orang yang 'sombong' mengatakan

Covid19 tidak bahaya, tidak mematikan,

Yang meninggal itu bukan karena serangan covid19

Tetapi karena penyakit bawaan

Yang meninggal itu karena kepanikannya sendiri.

Sekarang? Terbukti!!

Fakta terejawantahkan

Nyata tak terbantahkan

Covid19 menebalkan lendir yang menyumbat pernafasan, Saat terpapar, maka pupuslah semua harapan.

Meski ayat alam telah dipertontonkan

Kelompoknya masih saja meremehkan

Tidak ada orang yang meninggal karena serangan covid

Kalau Allah memutuskan maka manusia akan mati tanpa rumit.

Titik.

Tidak perlu khawatir, berjamaah di masjid, tabligh akbar. Ini adalah kesombongan atas nama takdir 
Mereka lupa bahwa Allah membuat kun

Dan mem-fayakuun-kannya dengan fenomena 'sebab akibat'

Agar manusia mau belajar, dan tidak meremehkan.

Bila Allah telah mengambil keputusan 'akan'

Maka terjadilah proses alami keputusan itu.

Covid 19, bala tentara Allah untuk menundukkan kesombongan manusia.

Orang yang meremehkan, tak berupaya menyelamatkan diri

Adalah orang yang 'sombong'.

Kita secepatnya harus tunduk menjaga diri dari 'kesombongan' ini.

Karena Allah tidak suka kesombongan dan karena kesombongan itu hanya milikNya

Tentara Allah ini tidak terkalahkan, tidak bisa kita usir dari bumi.

Mereka akan pergi sendiri pada saatnya, kala fayakuun.

Rendahkan hati serendah rendahnya,

Menyerah dan menyatakan kalah.

Tak perlu menyerang dan berharap menang

Cukup mempertahankan diri, berhati hati

Berdoa memohon ampun dan perlindungan agar diselamatkan,

Bila saatnya meninggal, khusnul Khotimah petanda ajal.

Ya Allah 'Aku kalah', aku mohon ambil kembali covid19 dari bumi ini.

Aamiinn. 
*Penulis, Prof. H. Mohammad Adnan Latief, M.A, Ph.D, adalah Guru Besar bidang Pembelajaran Bahasa Inggris, Fakultas Sastra, Universitas Negeri Malang, Jawa Timur.

64 Sastrawan Covid-19 


\section{LAA ILAAHA ILLAA CORONA?}

Syukron Makmun*

Corona

Corona

Corona

Semua menyebut nama corona

Membicarakannya

Mendiskusikannya

Mengingat-ingatnya

Mewaspadainya

Takut padanya

Siapa dia?

Begitu hebatkah dia?

Tak tertandingikah dia melebihi Tuhan?

Akankah kematianku dengan Laa Ilaaha illaa Corona Padahal tiap waktu ku ucapkan Laa Ilaaha illaAllaah? Saya berlindung darinya

*Penulis, Syukron Makmun, S.Pd, adalah Pengajar di Pondok Pesantren Mahasiswa Al Fatih Kota Cirebon, Jawa Barat 


\section{LAKON TERDEPAN \\ Rebbeca Arju*}

Bulan lalu, keluarganya bahagia

Tersirat penuh suka tawa.

Sceen ini berakhir dan sang sutradara mengganti takdir.

Jiwa bagai terlepuh air didih

Terkelupas perih, rintih

Mengiyakan pujaan hati,

Ayah dari putra putri,

Berada di garis putih

Siap berlari, sekencang mungkin, menggunakan pengaman diri.

Sang istri menggigil dalam setiap doa untuknya

Sambil terus mengusap air mata, di hadapan anandanya.

Ikrar suci telah terpaut di sanubari sang suami, tak dapat diubah

Menjadi lentera dengan balut baju suci

Mengabdi sepenuh hati, walau mati tak mudah dihindari.

Sang istri dan putra putri, tak mampu menahan lagi Menengoknya berselipan di antara dinding-dinding putih Sekedar memeluknya sejenak dan menyimpan rasanya abadi.

Hingga benar, tepat hari itu

Sangkakala memekak telinga

Raga sang dokter terjangkit korona.

Ia bertahan, dan harus bergegas siap di antrian ajal. 
Dengan hati yang hancur, ia berpamitan

Di pelataran, tak berdaya memasuki kediaman.

Sang istri ingin menerjang

Putra putri teriak lantang "papaaaa..."

Senyumnya teruntai-berucap ikhlaskan, walau masih mengemis harapan.

Lambaian tangannya mengakhiri perjumpaan, kesempatan terakhir.

Tiap detik pun hanya menyisakan spekulasi keajaiban.

Menginjak petang, panggilannya datang

Mengukuhkannya sebagai pahlawan

Syahid wabah yang budiman,

Walau puisi ini tak mewakili sedikitpun dari asa yang dipersembahkan

Namun.,,,

Bagimu beribu kembang

Bagimu berjuta sayang

Bagi kami, kau tak sekedar untuk dikenang

Perjuanganmu adalah sejarah yang takkan lekang.

Terima kasih kami yang terdalam, bagimu para lakon terdepan.

*Penulis, Barotun Mabaroh, SS, M.Pd, adalah dosen di prodi Pendidikan Bahasa Inggris, Fakultas Pedagogi dan Psikologi, Universitas PGRI Wiranegara (UNIWARA) Pasuruan, Jawa Timur. 


\section{MAHKOTA ITU}

\section{Effendi Kadarisman*}

Corona, the crown, mahkota itu-

Apa yang kau ingat?

Merek mobil tahun 70-an:

Corolla, Corona,

yang pamer pamornya di jalanan.

Kini Corona jadi merek virus,

yang halus menghembus

dan menggerus

hidupmu dan hidupku.

Kita diam, termangu.

Kita diam di rumah.

Termenung. Bercermin berlama-lama,

Bertanya: apakah makna reriungan

dengan istri dan anak-anak?

(Itu kenduri kebahagiaan.)

Siapa yang tak kagum?

Ah, Home Sweet Home

Lagu itu mendesah

dari celah buku sejarah.

Tapi Corona tak peduli

Ia virus bisu tuli

Ia merampas apa saja

Hari-harimu

Kemerdekaanmu

68 Sastrawan Covid-19 
Kebersamaanmu

Kau tak bisa lagi

Kumpul-kumpul, ketawa-ketiwi.

Tiba-tiba Corona menyanyi “Ibu Pertiwi”.

Benar, tentang Bumi

yang hari ini dibebaskan

dari bising dan polusi

dari sampah industri

dari amarah dan serakah.

Udara bernapas bebas

Langit kembali menemukan warna birunya

Laut tersenyum jernih

Luka lubang ozone sayup-sayup menutup.

Semesta pun terpukau oleh Mahkota itu,

"Terima kasih, Corona."

Dan kita masih diam di rumah

Kau berbisik kepada-Nya lewat ayat-ayat

Aku rindu pada Rumi, yang mengajariku:

"Hamba hanya sebutir debu

pada jalan-setapak kekasihku, Muhammad."

Tiba-tiba Corona menyahut:

"Aku 1/1000 debu,

yang mengantarmu ke gerbang kiamat."

Dan usia pun menggigil,

Di bawah tatapan tajam Izrail. 
Bukan, ia bukan virus bisu tuli,

Cuma tak paham sengsara,

Tak kenal batas negara.

"Imagine there's no countries," kata John Lennon.

Itu, dulu, angan-angan.

Corona bilang, "Jangan

berandai-andai.

Aku wabah. Aku badai."

Ah, sudahlah, Corona

Aku saksi, dan kau inspirasi

Sajak ini kutulis untukmu

Karena engkau adalah Mahkota

Dan aku Cinta.

*Penulis, Prof. Effendi Kadarisman, M.A, Ph.D, adalah Guru Besar Linguistik dan pakar Etnopuitika, dosen pada Jurusan Sastra Inggris, Fakultas Sastra, Universitas Negeri Malang, Jawa Timur.

70 Sastrawan Covid-19 


\section{MAKHLUK PENCIPTA}

Miftahul Khoiri*

Tuhan, aku berteriak pada-Mu

Bukan aku tak beriman pada-Mu

Tapi aku ragu dengan imanku

Iman yang dulu selalu aku pupuk

Namun kini mulai lapuk

Karena ciptaan $\mathrm{Mu}$, aku berpaling dari-Mu

Aku kadang menuhankan benda

Kadang menuhankan sesama manusia

Hanya jalan itu yang bisa aku lakukan

Aku selalu takut pergi kerumah-Mu

Aku selalu pesimis dengan Rejeki yang Kau turunkan

Walaupun aku sadar semua ini sebatas peringatan

Tapi ini adalah suatu kenyataan yang mengharuskan untuk aku lakukan

Entah makhluk macam apa ini Tuhan

Yang membuat semua orang ketakutan

Mengalahkan takutnya pada yang Menciptakan

Aku mohon, musnahanlah ciptaan-Mu yang satu ini.

*Penulis, Miftahul Khoiri, M.Pd, adalah dosen di prodi Pendidikan Matematika, Fakultas Pedagogi dan Psikologi, Universitas PGRI Wiranegara (UNIWARA) Pasuruan, Jawa Timur. 


\section{MATA KETIGA}

\section{Azizah Hefni*}

Kata ibu, mataku indah.

Menyimpan madu bunga.

Menyimpan suka cita.

Aku suka mataku, ibu.

Kulihat puluhan capung dan kumbang di kebun

Hujan semalam yg menyisakan embun

Bunga bunga yg bersenandung

Orang orang yang tersenyum

Lalu matahari,

Ibu yg bernyanyi di depan tungku api

Ayah yang menari kecil di dekat serambi

Dunia ini seperti petasan warna

Gemerlap dan gembira

Seriap orang melangkah

Mencari mereka, mencari ceria, mencari tawa, mencari

kerabat,

Mencari tetangga, mencari keluarga

Mencari cita cita.

: menggenggam dunia

Mataku, melihat itu ibu.

Sekuntum mawar yg dihinggapi kupu kupu. Disesap.

Diresap.

72 Sastrawan Covid-19 
Tapi, kata ibu, ada mata ketiga dalam diriku.

Mata rahasia.

Mata yg hanya bisa melihat dengan pejam.

Segala yg tak kasat

Tak tampak

: mata sunyi.

Ribuan makhluk yg hidup

Ribuan ruh yg berdenyut

Yg lebih tipis dari ari

Lebih lembut dari kapas

Lebih kokoh dari besi

Lebih tunduk

Lebih patuh

Aku memejamkan mata.

Menyusuri bilik mataku yg ketiga.

Oh... seperti menggali liang semut

Menelusuri lubang tikus

Menemukan sarang ular

Menyusuri hutan tanpa matahari

: aku berteriak.

Lalu kulihat dunia yg cemerlang tertutup kabut.

Orang orang bersembuyi dalam rumah rumah

Menangis memendam rindu

Perjumpaan yg tertutup kabut

Pesakitan yang tumbuh berserabut

Kematian yang menyisakan pilu dan takut. 
Bunga bunga berhenti bernyanyi

Kebun kebun penuh capung dan kumbang kering dan sepi

Ibu dan ayah sembunyi

Teman teman mengurung diri

Diam.

Tak ada putaran dan getaran.

Cekam.

Tak ada pelukan

Dan jabat tangan

Mata ketigaku gerimis.

Ada ribuan makhluk terbang

Menari di udara yang kelabu

Berdendang seperti katak menyambut hujan.

Mengaum seperti singa yg kekenyangan.

Kecil.

Yg lebih tipis dari ari

Lebih lembut dari kapas

Lebih tunduk

Lebih patuh.

Dan berdenyut.

Mencari hidup.

Memuji Tuhan

Memuji keberadaan.

Apa kau iblis? Tanyaku.

Kau menari di tengah derai air mata.

74 Sastrawan Covid-19 
Kau membusungkan dada di tengah lara dan duka manusia.

Kau menyakiti raga yg renta

Kau hinggap menusukkan benalu pada nafas nafas yg penuh harapan.

Bukan. Aku bukan iblis.

Lalu apa?

Aku milik Tuhan yg patuh

Dicipta

untuk menari di atas kepala manusia yg

hiruk

Sibuk

Tuli pada tangis

Buta pada sakit

Hidup pada mati

Itu sama dengan iblis, teriakku!

Tidak! Aku bukan iblis!

Kau jahat pada bumiku.

Pada temanku

Pada keluargaku

Pada tetanggaku

Pada saudara bangsaku

Pada saudara manusiaku!

Mata ketigamu, masuklah ke dalamnya. 
Kau akan tau, bahwa iblis hanyalah serpih yg tunduk

Tunduk untuk membenci

Tunduk untuk menyakiti.

Akupun juga.

Serpih untuk hidup

Dalam tubuh manusia manusia yg sering lupa.

Dalam paru paru manusia yg sering salah

Aku hanya tunduk.

Hanya patuh.

Pada Tuhanku.

Yg juga Tuhanmu.

Gegas aku membuka mata.

Mata ketigaku,

Membuatku merapal doa doa.

Aku serpih.

Dia serpih

Kau serpih

Mereka serpih

Iblis serpih

Malaikat serpih.

Juga mereka yg kecil itu,

Virus virus yg mencari inang.

Mereka pun serpih.

Yg digdaya hanyalah Tuhan.

76 Sastrawan Covid-19 
*Penulis, Azizah Hefni, S.HI, adalah penulis buku "Mendidik Buah Hati Ala Rosulullah", penulis novel "Pertemuan di Rintik Hujan" dan "Sabar itu Cinta", sertaowner Humaira Design and Art, Yogyakarta. 


\title{
"MBOK, AKU ORA ISO MULIH"
}

Bapake Satrio*

\author{
"MBOK, AKU ORA ISO MULIH" \\ Itulah isi singkat telponku \\ Bahwa.... \\ Lebaran ini, aku ora mudik \\ Keluarga kecilku menyadari \\ Bapak-ibuku mengerti \\ Bapak-ibuk mertuaku memahami \\ Keluarga besarku, semua memaklumi
}

Memang ini ujian kesadaran dan kesabaran

Semua karena korona

Semua demi kebaikan

Kebaikan untuk semua

Kebaikan kami, kamu dan kita

Memang butuh kesadaran dan kesabaran

Meski belum terbayang

Lebaran tanpa keluarga besar

Meski belum terpikirkan

Apa yang akan kupikirkan

Lebaran hanya di rumah saja

Apa yang mesti kulakukan

Tapi

Yang kutahu

78 Sastrawan Covid-19 
Harus tetap di rumah saja.

Aku tahu, ini tidak mudah

Butuh kesadaran dan kesabaran

Inilah untuk yang pertama kali

Lebaran di rumah saja

*Penulis, Dr. H. Daryono, M.Pd, adalah owner Daryono

Property dan sekaligus dosen di prodi Pendidikan Pancasila dan Kewarganegaraan, Fakultas Pedagogi dan Psikologi, Universitas PGRI Wiranegara (UNIWARA) Pasuruan, Jawa Timur. 


\section{NEGERI NGERI}

Rebbeca Arju*

Hai hai hai horang kaya

Lihatlah di pelataranmu para janda

Luntang luntung cari nafkah

Karena nasi jagung paginya tak boleh dijual sebab corona

Hai hai hai intelektual

Di sebelahmu bapak bapak kumal

Memaksa diri mendapatkan bekal

Untuk anak istri yang menunggu di rumah terpal

Hai hai hai para dewan

Tolonglah wakili kepanikan kami

Jangan kau panik sendiri,

Menandatangani kertas untuk menambah pundi-pundi

Seakan kau dan keluargamu sendiri yang mengadapi

epidemi

Blusuki kami, yang kala itu tulus memilih tanpa serangan nasi

Hai hai hai para artis

Yang katanya berkulit glowing klinyis

Penampilan pasti necis

Digit ATM tak pernah tipis

Ini saatnya, figurmu terlukis

Di hati para papa yang setia menontonmu, dan tentu tidak gratis.

80 Sastrawan Covid-19 
Entah siapa lagi yang akan ku dakwa Untuk peduli kanan kiriku yang telah terkapar lara Sedang aku hanya mampu membawa segelas air dan kurma

Aduhhh duh duh duh Mereka-diaspora tak memiliki negara Ironis, zionis, mereka makmur-terjamin, dan sejahtera Tapi oohhh emmaaakkk bapaaakkkk

Ini pak lik tak tahu harus kemana lagi mengemis Sedang perut sudah kempis Napaspun sudah hampir tak berdesis Ataukah memang benar cukup berdiam diri Di bilik-bilik tanpa uluran kasih Dan..

Inilah negeri ngeri

*Penulis, Barotun Mabaroh, SS, M.Pd, adalah dosen di prodi Pendidikan Bahasa Inggris, Fakultas Pedagogi dan Psikologi, Universitas PGRI Wiranegara (UNIWARA) Pasuruan, Jawa Timur. 


\section{NEGERIKU SEDANG SAKIT}

Ika Puspita*

Negeri sedang sakit...

Ramadhan tahun ini sangat jauh berbeda

Ada banyak perubahan.....

Tidak ada semarak taraweh berjam'ah

Masjid dan mushola ku sepi...

Tidak ada keceriaan tadarusan dan kajian Ramadhan...

Lagi, Masjid dan mushola ku sepi...

Bahkan berbuka dengan kawan atau handai taulan pun

tiada

Negeriku sedang diuji

Negeriku malang Negeriku sayang

Negeriku sedang berduka, sakit, dan harus segera bangkit

Ramadhan tahun ini dirumah saja...

Tak mengapa... Karna Dia takkan pernah membiarkanku

larut dalam duka

Dalam tiap lirih suara Alquran yangku baca, ada Allah yang

maha mendengar

Dalam untaian doa, Ada Allah yang maha Pemurah

Negeriku sayang, segeralah bangkit

Agar Ramadhan tahun ini kembali ceria

${ }^{*}$ Penulis, Ika Puspita, S.Kom, adalah staff administrasi di Universitas PGRI Wiranegara (UNIWARA) Pasuruan, Jawa Timur.

82 Sastrawan Covid-19 


\section{NYANYIAN SEMESTA}

Tri Kristianti*

Pernah ada suatu masa

Kala semua tampak indah dan sempurna

Bumi berpenghuni dan langit begitu cerah

Bocah-bocah kecil berlarian mengejar waktu

Saat sang pemberi ilmu menanti di gerbang sekolah

Dan berulang dan berulang dan berulang

Hingga semesta merasa bosan

Dengan kisah penghuni bumi yang tak bijak dalam berperi

Dan membiarkan corona menyapu bersih segala cerita meninggalkan pedih

Seolah melukiskan batas keteguhan manusia tak berarti

Bangkit dan berjuang! pesan Corona pada dunia

Sapu bersih penyakit hati! Bisik Corona mendekat

Berubahlah! sahut Corona sambil tertawa

Lalu sunyi

Lalu sepi

Lalu terlelap

*Penulis, Tri Kristianti, S.Pd, M.Pd, adalah dosen Bahasa

Inggris, Fakultas Teknik Universitas Wisnuwardhana

Malang, Jawa Timur. 


\section{PAGEBLUK CORONA}

Junaidi Abdillah*

Engkau mencintai kami dengan "Brutal",

Memaafkan dan melupakan kebodohan kami sekaligus

tanpa jeda,

Sejak Bapak Adam dan Ibunda kami, Hawa.

Sejak Engkau kirimkan makhluk-MU yang bernama Corona,

Terlonjak kami, disadarkan pada Bala'-MU yang pernah

Engkau timpakan pada umat terdahulu yang durhaka, Merengek - rengek kami, minta diselamatkan, serupa Umat Nuh dengan Bahtera besarnya.

Tersadar kami, bahwa Engkau ada, sebelum kata ada itu ada,

Lupa bahwa Engkau Raja Di Raja selamanya.

Duh, Gusti Pengeran, Atas Nama Kekasih-MU, Sayyidina Muhammad yang yatim, Ampunilah selalu Kami, Manusia, hamba-MU, pelacur-MU, budak-MU, wayang-MU

*Penulis, Junaidi Abdillah, S.Psi, adalah owner Rumah Rajut Jember. 


\section{PAHLAWAN BERMASKER}

Shohib Cinta*

Keluarga kalian tinggalkan...

Nyawa kalian pertaruhkan...

Kesembuhan pasien corona selalu kalian prioritaskan...

Wahai pahlawan bermasker...

Sungguh mulia hati kalian...

yang rela jadi garda terdepan demi hidup manusia...

Wahai pahlawan bermasker...

Sungguh mulia hati kalian...

yang rela mempertaruhkan segalanya

demi sebuah nyawa...

Wahai pahlawan bermasker...

Siang dan malam kalian terus berusaha tanpa kenal lelah... hingga terkadang makan dan minum pun kalian lupa...

Wahai pahlawan bermasker

Kalianlah mentari kehidupan...

Dan senja keindahan dalam kehidupan...

Kalianlah malaikat penolong menjadi penumpuh seribu harapan untuk kesembuhan..

Wahai pahlawan bermasker

Tetaplah semangat dalam melakukan misi kemanusiaan...

*Penulis, Shohibul Hujjah, S.Sos, adalah CEO Kabarpas

Pasuruan (PT. Media Masyah Publika) 


\section{PASIEN PANDEMI}

Murasaki*

Di antara panas membakar

Dia datang membawa kabar

Meneriakkan warna-warni kehidupan

Daun hijau segar membungkus adonan

Masih tertata rapi dalam keranjang

Lemper, ya buat kita yang sedang lapar

Cokelat pekat terasa nikmat

Brownies bertabur keju berdamping dengan kerupuk dan wingko babat

Panas matahari tidak bisa membohongi

Peluh bercucuran menetes dari ujung kepala sampai kaki

Terlihat jelas pada dahi

Tertunduk lesu di trotoar menanti pembeli

Saat sepi, kau kayuh lagi sepeda usangmu

Berharap ada panggilan di tengah suara sepeda tuamu

Mengitari jalan kota yang penuh pandemi

Tiada hari yang kau sesali

Tiada virus yang kau takuti

Demi sesuap nasi yang kaucari

Untuk penuhi tanggung jawab diri

Di depan gedung megah kau singgah

Menanti dan menguliti hati kami yang iba

Pak Tua penjual aneka kue basah

86 Sastrawan Covid-19 
Masih setia dengan baju putihnya

Kuhampiri dan kubeli

Meski tak kautawarkan lagi

Aku mampu menghitung upah yang masih tertinggal di

kotak roti

Berjejer rapi seolah semutpun enggan menggampiri

Memilih tanpa kunikmati

Karena sedari tadi kulihat senyummu menghiasi tatapan kosong di kotak guci

Tiada uang kembalian, suara pelan memecah arena pandemi

Menambah deretan derita kami

Bukan hanya yang terpapar virus corona yang menjadi pasien pandemi

Dia juga terpapar dampak virus corona di jalanan yang sepi

Tak kuasa berteriak di hamparan sunyi

Semua rumah tertutup dan terkunci

Kaumasih terduduk menyanggah sepeda tua dengan mendekap kotak putih

*Penulis, Sugianti, M.Pd, adalah dosen di prodi Pendidikan Bahasa dan Sastra Indonesia, Fakultas Pedagogi dan Psikologi, Universitas PGRI Wiranegara (UNIWARA) Pasuruan, Jawa Timur 


\section{PELANGI MUHASABAH}

Zahrotul Muzdalifah*

Terik mentari semesta menghangatkan hari

Udara pun elok sejuk membuai pagi

Namun rasa khawatir tetaplah menghampiri

Pada jiwa jiwa yang menanti dengan setia

Menunggu perginya kabar wabah lara

Untuk rekah senyum dan syukur tak terhingga

Hujan deras kian rutin beritme panjang

Seolah bertitah pada diri untuk melapang

Menyelami segala perbuatan insani

Yang sungguh menyita ikhtiyar ragawi

Bahkan terkadang lupa bertakdzim diri

Pada sang pemilik mentari pagi

Maka sungguh baik harus bersabar hati

Dengan pandemi yang mengintai mati

Biarkan hujan deras mengalunkan melodinya

Dan mentari memainkan cahayanya

Maka dengan pelangi musahabah padaNya

Perahu ikhtiyar akan bersandar pada dermagaNya

Allah Gusti ampuni kami ini

Yang tak kenal lelah mengejar duniawi

Sampai lupa pada negeri samawi

Yakni perjalanan indah berbau surgawi

Maka terimalah peluh dan lelah ini

88 Sastrawan Covid-19 
Dalam ikhtiyar bersabar dan berdiam diri

Dan berpuasa dan ibadah dalam penantian Menjadi bekal penguat kami nanti

Di hari Akhirat yang kan tiba kemudian lagi

*Penulis, Zahrotul Muzdalifah, S.Pd, adalah mahasiswa Magister Keguruan Bahasa Arab, Universitas Negeri Malang dan mengabdi sebagai Musyrifah Ma'had Darul Hikmah MAN 1 Kota Malang, Jawa Timur. 


\section{PEMANTIK}

Rini Damayanti*

Pemantik waktu

Tak padam dalam gelap

Perlu tekanan menyalakannya

Asap akan mengitarinya

Kau jentikkan pemantik

untuk menghisap semua warna

sebuah dimensi yang terlupa

Pemantik dijentikkan

diatas waktu yang ditentukan

tiap titik yang tertarik

kutulis doa di kertas secarik

Tak ada lagi intrik

Tak ada lagi polemik

Tak ada masalah yang pelik

Agar ada asa setitik

dan pada akhirnya semua akan kembali di akhir detik bumi membaik

manusia tak lagi tercabik

doa terlantun untuk yang terbaik

*Penulis, Rini Damayanti, S.Pd, M.Hum, adalah dosen di prodi Bahasa Indonesia, Universitas Wijaya Kusuma Surabaya, Jawa Timur. 


\section{PERCIKAN COVID - 19}

Kustyarini*

Langit mulai sinis menatap bumi

Percikannya bekukan urat-urat kilat bumi

Cipratan yang mengatasnamakan Covid-19

Merambah sendi-sendi..

Komat-kamit berharap terhindar dari Covid

Merenda kebisuan sampai kapan yang entah

Menata puing-puing gundah di relung hati

Kabar kematian menjadi kudapan harian

Lekuk-lekuk jenuh mulai merayap

Pada sendi-sendi tulang -belulang

Begitu lamban terasa waktu

Seakan menyekap jiwa yang kerdil, memupus kuncup

Suara jangkrik pekarangan rumah pun hening

Tertelan Surat-Surat Edaran Pejabat pemagar gerak

Tapi tidak..sekali lagi tidak

Lengkingan Covid isyaratkan tentang kita

Kita pernah lupa..

Tentang jamban-jamban kecil gemericik di depan sana

Bersihkan segara rupa

Ciptakan segala rasa

Jendela warna surga di dinding rumah kita

Adalah yang tak terkira saat semula

Canda keluarga pelipur segala rasa

Do'a kita adalah pemandu di setiap helaan napas 
Urat-urat nadi tetap bergetar berirama

Sambil menunggu bintang soraya berpancar

Menggantikan Covid kembali pulang ke kandangnya

*Penulis, Kustyarini, M.Pd, adalah dosen Prodi Pendidikan

Bahasa dan Sastra Indonesia, Fakultas Keguruan dan Ilmu

Pendidikan, Universitas Wisnuwardhana Malang, Jawa

Timur

92 Sastrawan Covid-19 


\section{PERJUANGANMU}

Laily Fitriani*

Padang lara terhampar

Kita bukan sedang berpesta, Kawan

Gelombang virus sedang mewabah, sporadis

Dan engkau berdiri tegak

Nanar aku menatapmu

Desik angin menghilirmudikkan isi kepala

Mengajakku bercanda

Atas dasar apa engkau datang?

Puluhan, ratusan hingga ribuan bahkan jutaan virus

mengintai

Engkau garang, walau penuh waspada

APD terjerembab dalam tubuh penuh semangat

Engkau tetap ada di garda terdepan

Rinai senja bertabur duka

Mengantarkan nama pada Sang Maha Kuasa

Harsamu telah terpahat

Dalam catatan sejarah kemanusiaan

*Penulis, Dr. Laily Fitriani, M.Pd, adalah dosen Pascasarjana di Universitas Islam Negeri (UIN) Maulana Malik Ibrahim Malang, Jawa Timur 


\section{PETANDA APA, CORONA? \\ Segera Sirna Tanpa Korban Nyawa \\ 'Abd Al Haris Al Muhasibiy*}

Ya Allah, segalanya di tanganMu.

Meski sudah berusaha dengan penuh.

Misteri dibalik apa yang terjadi tidak tahu.

Para dokter dan ahli kesehatan sudah berpeluh.

Upayakan bisa usir corona setiap waktu.

Namun katanya sih...masih tetap tidak mau.

Masih saja datang dan senang mengganggu.

Sebagai manusia sudah berusaha.

Dengan memakai cara dan usaha apa saja.

Mengapa ya Allah...corona tidak mau enyah.

Bahkan justru menakut-nakuti siapa saja.

Mereka seperti burung ababil yang menyerang abraha.

Tapi kami yang beragama juga bisa saja kena.

Mengapa ya Allah....sungguh kami hampir putus asa.

Semua panik seperti tertekan ketakutan luar biasa.

Hanya Engkau yang tahu misteri.

Meskipun orang bilang ini pandemi dan epidemi.

Entahlah yang benar-benar-benar tidak diketahui.

Mungkin ini sebuah simbol yang menunjuki.

Sesungguhnya kami sudah tidak lagi bersahabat di bumi.

Sering perankan drama palsu tidak asli.

94 Sastrawan Covid-19 
Ya Allah....tetap kami mohon ampuni.

Segala khilaf dan salah yang tidak terhitung lagi.

Ilahi... lastu lilfirdausi ahla, wa la aqwa 'ala naril jahimi.

Fahabli taubatau waghfir dzunubi.

Fainnaka ghafirudzanbil adzimi.

*Penulis, Prof. Dr. H. Abdul Haris, M.Ag, adalah Guru Besar/ Rektor Universitas Islam Negeri (UIN) Maulana Malik Ibrahim Malang, Jawa Timur. 


\section{POWERLESS}

Fitrana Harintama*

Hai kamu,

Yang banyak dibenci, dicaci

Diinginkan untuk pergi

Entah apa inginmu

Kami masih meraba untuk tahu

Kamu membawa sengsara

Namun di baliknya,

Kamu memberi waktu bagi kami untuk bermesra

Dengan keluarga,

Bercengkrama dengan Tuhan

Menangis bersujud

Bersimpuh tak berkekuatan

Tiada daya kami terhadapmu

Keangkuhan sirna tak berbekas melawanmu

Pun melihatmu kami tak bisa

Rasa takut tak selalu pada yang terlihat

Namun kami tahu engkau nyata

Kami yakin kau akan pergi

Saat kau tak lagi berkeinginan

Sampaikan salam kami pada Penciptamu

Betapa kami tak lebih kuat daripadaNya

Tak ada kuasa melawan rencanaNya

96 Sastrawan Covid-19 
*Penulis, Fitrana Harintama, M.Pd, adalah pengajar di Lembaga Pengembangan Pendidikan (LPP), Nusa Tenggara Barat.

Antologi Puisi: Covid-19, Radang \& Ladang Kehidupan 97 


\section{PUISI PAGI}

E. Yoohana*

Mungkin, usai juang ini kita kan menang

atau kan tumbang?

Biarkan angin yang membisikkan jawaban

Puisi pagi, yang teriring melodi,

Tak kalap hati, berbelah sunyi.

Libur korona kian memanjang,

Datang tak pernah diundang,

Jua tak kunjung pulang.

Metropolitan kini membara,

Kota sang Proklamator pun merah berwarna.

Cuitan warga soal sembako, kini semakin minim di toko, Memilih berkawan ego,atau berperan bak kerbau Sama-sama tak bisa merasakan sedapnya soto

Sujud tubuhmu, ucap doa pada Illahi, Korona kian pergi, Bumiku kan berseri.

*Penulis, Elva Yohana, S.Hum., M.Pd, adalah dosen Tadris Bahasa Inggris, Fakultas Tarbiyah dan Ilmu Keguruan, IAIN Tulungagung, Jawa Timur. 


\section{RAMADHAN BERJARAK}

Novia Dwi Rahmawati*

Lembayung senja Sya'ban telah beranjak pergi.

Tergantikan secara epik Ramadhan Pagi.

Ya...Ramadhan Kareem tahun ini berjarak.

Sholat tarawih dirumah, terlihat masjid beratap limas segi empat itu sepi.

Tadarus dikumandangkan di kediaman sendiri

Safari Ramadhan wajib ditiadakan.

Ya...Ramadhan kali ini terasa beda.

Kita dihadapkan suasana pandemi Covid-19.

Lalu aku berpikir sejenak..

Apa yang harus kulakukan saat Ramadhan Kareem yang berbeda ini?

Deret amal tak memiliki pola pasti

Fungsi pembangkit hanyalah ridho ilahi

Aku berpikir menemukan pemecahan masalah ini,

Tapi tersadar diri tak mampu berfikir tingkat tinggi

Malam 1000 bulan berpeluang yang sama di Ramadhan berjarak

Nuzuulul Qur'an pun hadir, tanpa kita menyambutnya

bersama. Iya cukup di rumah

Mari kita perbaiki hubungan dengan manusia (Hablum Minannas)

Sumbu ordinat di garis $\mathrm{X}$ ini 
Dan Mari kita perbaiki hubungan dengan Allah SWT (Hablum Minallah)

Ordinat di garis Y yang harus dijaga dengan tahan diri

Ya Ramadhan kali ini terasa beda dan berjarak.

Bagaikan dua titik yang terhubung satu garis lurus dengan jarak

Aku berada di titik adjacent dan ramadhan di titik incident.

*Penulis, Novia Dwi Rahmawati, S. Si., M.Pd, adalah dosen di Prodi Pendidikan Matematika, Universitas Hasyim Asy'ari, Jombang, Jawa Timur 


\section{RASA ITU \\ Dina Amaliyah Mushthoza*}

Bermula perjalanan luar negara

Berkeliling dari kota ke kota

Bersua dengan banyak orang

Berdekatan tak ada yang melarang

Vaksin terlupakan

Kebersihan kurang diindahkan

Menjadikan suhu tubuh naik

Karena lelah tak jadi panik

Oh, virus mulai menggoda

Bersin berulang ulang

Terasa tubuh begitu meriang

Tenggorokan menggelitik gatal

Bagai sesuatu masuk dan mengganjal

Menuju paru-paru dan menyebar

Nafas pun ngos-ngosan

Semakin menguji kesabaran

Barulah terasa

Tiada lagi yang dapat terlaksana

Hanya Dia-lah yang teringat

Istighfar selalu terpanjat

Penawar tak terhitung

Nutrisi tak terbendung

Usaha tak kunjung hilang

Mental tak perlu tegang 
Pasrah setelah bertawakkal

Ketenangan jiwa menjadi penangkal

*Penulis, Dina Amaliyah Mushthoza, M.Pd, adalah dosen di Universitas Qomaruddin Gresik, Jawa Timur

102 Sastrawan Covid-19 


\section{RENDAH HATI}

Moh Ali Aziz*

Sore hari, seorang ayah memangku putri kecilnya Berbisik lirih kepadanya

"Nak, semoga kau menjadi putriku yang rendah hati."

Putri kecil menatap lembut, memainkan sorban ayah

Masa pun berganti

Kini ia baru memahami

apa maksud rendah hati setelah membaca sejarah nabi

Selalu senyum dan tak pernah mencaci

Tak pernah marah walau diludahi

Selalu menyemangati bak matahari

Juga bak bulan, pengusir gelap di malam sunyi

Memberikan baju yang paling disukai

Selalu berkeringat membantu istri

Walaupun ia pemimpin semua Nabi

Kita sering berpenampilan orang suci

Tapi, hati kita sebusuk bangkai

Ajaran keadilan hanya tajam untuk orang lain, tapi tumpul untuk diri sendiri

Anggaplah diri tak bernilai di mata sendiri

Tapi terhormat di mata setiap yang mengamati

*Penulis, Prof.Dr. KH. Moh.Ali Aziz, M.Ag, adalah guru besar bidang Da'wah, Universitas Islam Negeri (UIN) Sunan Ampel Surabaya, Jawa Timur dan pendiri Kun Yaquta Foundation. 


\section{RETORIKA HATI UNTUK PANDEMI}

Tri Kristianti*

Hari ini dunia kita sama

Kau, aku dan kita karena dia

Tak lagi mendengar berita yg berbeda

Tak lagi berdebat tentang bangsa

Hati kita diuji sebagai manusia

Mengukir rindu, luka dan cinta

Dihadapan wabah pemilik udara

Mengorbankan jiwa2 tak berdosa

Kita begitu kecil

Mungil dan dekil

Kesombongan tak lagi kekal

Doa2 kita selalu jadi penawar

Demi kejahatan kita

Demi kerakusan kita

Demi kebohongan kita

Kita tersungkur bersujud

Agar kehidupan kembali terwujud

Jutaan manusia telah terinfeksi

Puluhan ribu telah mati

Meninggalkan pesan yg sempurna

Sebagai makhlukNya kita bukanlah penguasa sebenarnya

*Penulis, Tri Kristianti, S.Pd, M.Pd, adalah dosen di Fakultas

Teknik Universitas Wisnuwardhana Malang, Jawa Timur

104 Sastrawan Covid-19 


\section{RINDU}

Rini Damayanti*

Saat ini sangat kurindukan

Sebentuk pertemuan, menghabiskan paruh hari

Untuk saling belajar

Lama tak kudengar

Canda tawa bergema

Riuh kata bercerita

Rengekan merajuk manja

Di seberkas bangku-bangku kosong tak bernyawa

Menantikan lagi kehadiranmu, kehadiranku, kehadiran kita

Kembali bersua

Dalam ruang kelas yang tak bernyawa tanpa kita

Anak-anakku .... Sabarlah menunggu

Hari itu akan segera tiba

Wabah ini akan segera reda

Agar kita kembali menyulam asa

Menghidupkan lagi kelas-kelas kita

Rindu bukan hanya milikmu saja

Rindu itu milikku jua

Melalui detik-detik waktu yang kian berdebu

Melangitkan doa agar semua baik-baik saja

*Penulis, Rini Damayanti, S.Pd, M.Hum, adalah dosen di prodi Bahasa Indonesia, Universitas Wijaya Kusuma Surabaya, Jawa Timur 


\section{RUMAH LABA-LABA}

Rebbeca Arju*

Sejak membiru,

Terlepas dari cangkang muliamu

Berjuta titipan telah kau emban

Dan kau pun menjadi satu alasan yang baru

Merancang setiap detik, menit, dan ribuan jam.

Tanpa kau tahu

Hidup bagai menahan gunung walau hanya dengan jemari

Bagi kedua malaikatmu

Beling dan api tak berarti pasti

Agar kau menikmati dolalan mu, menertawainya, dan

sesaat bosan-melupakannya.

Malaikatmu tetap memandangmu

Mengucurkan air mata dan jeritan hatinya

Biar semut menjauh, tak mencubitmu.

Selamanya kau bagi mereka adalah baru - masih biru.

Kini malaikatmu tak teraba

Tak tercium

Tak tersentuh

Kau dirundung duka beda dimensi, sedang burung-burung hanya mendengar siul lesumu

Dedaunan hanya menatapmu layu

Dan kau, tanpa pilih, bermain rumah laba-laba

Menyentuhnya, dan mendapati sawang yang seketika pasrah

Tangannmu pun bergetar tatkala kau sadar rumah itu

106 Sastrawan Covid-19 
Membungkus sabda cinta dari para penghuninya Simbol kalimasada, kau khalifahnya, Tapi....

Kau biarkan mereka terbirit tanpa pijakan

Tak kau hargai mereka ingin mendampingimu, Tak kau sadari mereka ingin melindungimu, Lalu kemana mereka berlari

Dan kau pun enggan memahami Malam ini, Sapaannya datang dalam mimpi

Bukan sekedar komunikasi, tapi ia patah hati Laba-laba, tak pernah ia persoalkan mengapa kau mempermainkannya, menggulung rumahnya Di saat ia ingin menjadi saksi atas setiap hurufmu Melihat tenang tidurmu, Mengikuti pikuk perilakumu, bak kedua malaikatmu-dulu

\section{Lirih}

Laba-laba bertanya masihkah kau merasa sebagai khalifah $\mathrm{ku}$ ?

Kau pun tak ciamik menjawab

Tak usah ragu, sebentar lagi kau akan menjadi laba-laba yang sama sepertiku

Tapi, aku manusia

Bersiaplah dengan jaring benang sutramu, rumahmu Corona sahabatku akan mengetukpintu-pintumu Ingin ku katakan khabar ini padamu Tapi tak cakap bahasaku menggapai nuranimu. Corona? kerutku 
Ia sahabatku yang kan membuatmu mengerti arti sebuah rumah, dan kautak bisabermain-mainlagi

Lalu, kau akan kemana?

Laba-laba itu berlalu menjauh

Tapi ia kembali-sejenak mencium pipiku; meliuri dan pergi Aku tertegun, ini bukan mimpi

Kini, corona si pendatang baru..

Nyata, menyayatku, mata jiwaku, lidah hatiku

Tak satupun yang tahu bagaimana ia datang, lalu dengan apa ia diusir?

Laba-labaku datanglah... bisikkan aku tentang si pendatang semu

Panggilku hampa, tak berbalas

Tapi masih jelas di hatiku, aku tak lagi-lagi bermain

Dan aku setia di jaring-jaringku, rumahku

Sungguh, hari masih pagi

Corona yang dini memperangah penduduk bumi

Menjegal setiap derap langkah kaki,

Bahkan sekadar untuk subjugasi, edukasi

Memaksa halu master plan ekonomi

Memanipulasi kepercayaan dan strategi

Oh corona terima kasih

Hari beranjak lebih terang,

Oh corona terima kasih

Di siangmu, kau menyadarkan "aku tak lebih dari labalaba"

Rumahku yang rapuh; 
Tumpukan reputasi, deklarasi, kemampuan diriyang kadang tak ada budi

yang malah sering membunuh hakikat terciptanya diri Meluluhkan secuil egoku.

Tanpa bertamu, kau telah porak porandakan rumahku Tapi aku bersyukur, karenamu

Mantra sakral lebih menggaung dari setiap kalbu Bukan lewat pengeras suara, bukan juadalam balutan jubah

Karenamu, kedua malaikatku, ayah ibu

Bahkan lebih sering mendengar dendangku di "sana"

Ku juga bisa menikmati dongeng ayah lagi

Peluk ibu lagi, damai sekali

Walau tak teraba

Tak tercium

Tak tersentuh

Mu'jizatmu corona, kasih beliau berdua sangat kuat menemani, menghiburdiri

Walau, pipi selalu basah merindu tanpa henti

Oh corona, terima kasih

Aku tak tahu bagaimana menghabiskan malam denganmu.

Mungkinkah kau berganti lagi dengan sahabatku

Laba-laba yang meliuriku

Karena aku ingin bercerita banyak tentangmu

Padanya..

Atau tetapkah aku menjadi laba-labamu, mainanmu Maka ku sungguh yakin, menjawab laba-labaku, aku bukanlah seorang khalifah. 
${ }^{*}$ Penulis, Barotun Mabaroh, SS, M.Pd, adalah dosen di prodi Pendidikan Bahasa Inggris, Fakultas Pedagogi dan Psikologi, Universitas PGRI Wiranegara (UNIWARA) Pasuruan, Jawa Timur.

110 Sastrawan Covid-19 


\section{SAJADAH LANGIT}

M. Alifudin Ikhsan*

Semua melangitkan permohonan tulus

Sepanjang pagi dan malam bersimpuh

Tanpa memandang dirinya siapa

Menghamba malu merasa hina

Sadar tak ada daya dan upaya

Menandingi keperkasaan pemilik segala

Ikhlas mengharap ridha kemurahan-Nya Memasrahkan segala keadaan pada-Nya Semua kita adalah milik-Nya

Ia kirimkan kasih sayang bukti keagungan-Nya Memberi kesempatan berduaan dengan-Nya Lebih lama tanpa gangguan kesibukan

Di tengah merebaknya Covid tentara-Mu Kau utus malaikat rahmat penyebar kasih

Di tengah gempuran stigma jahat musuh-Mu Kau berikan hela nafas segar bagi alam

Di saat carut marut tatanan bumi-Mu Kau hentikan kemaksiatan pun keserakahan

Allah ku pasrahkan semuanya pada-Mu Hidup mati berikrar suci mengharap ridha-Mu Berikan kami kesabaran Ayyub kekasih-Mu $\mathrm{Di}$ atas sajadah langit mengadu pada-Mu Sadar ketidakmampuan kami menghadapinya 
Pandemi corona memberi pelajaran hikmah Pun seolah berkata ingin mengubah sejarah Ya Rabb,

kami berharap cinta dan kemurahan-Mu

*Penulis, M. Alifudin Ikhsan, M.Pd, adalah Kepala Sekolah SMP Darul Faqih Indonesia dan Direktur Pesantren Mahasiswa Darul Faqih Malang, Jawa Timur 


\section{SAJAK RINDU}

Hariesta*

Rindu 1

Sebuah hari yang sama

Detik waktu melaju sesuai ritme yang disebut kerja

Terlambat menjadi alasan kuat berlari

Begitu terus tiada henti

Serasa hidup terasa beban

Akhir pekan jadi dambaan

Memajang gambar saat serunya liburan

Hingga adagium kurang piknik diberlakukan

Apakah lagi yang tak terbeli

Makanan transportasi akomodasi

Semua tinggal mainkan jari

Inilah dunia-dunia aplikasi

Kami bisa bersuka-suka tiada henti

Rindu 2

Semua pertemuan itu terasa berharga sekali sekarang

Padahal kesempatan masih ada

Padahal berharap masih boleh

Bagaimana jika penyesalan itu datang bila maut

menghadang

Kembalikan kami ke dunia O Tuhan

Untuk sujud sekali saja 
Merindukan hari normal

Saat perjumpaan bisa kapan saja

Ketika silaturrahim bisa setiap hari

Sewaktu berjabat tangan jadi sebuah kedekatan

Wahai makhluk Tuhan yang disebut Covid-19

Segeralah purna masamu bertugas

Kami beriktikad memperbaiki diri

Dalam mengisi hidup di muka bumi

Rindu 3

Manakah yang sungguh mereka inginkan

Wahai Rabb seru sekalian alam

Satu kali mereka ingin liburan esoknya ingin berjibaku di jalan

Tanya malaikat pencatat sambil merunut semua tulisan

Bahkan di hari mereka tercipta

Sebuah ragu atas status yang diembannya

Sebagai khalifah di muka dunia

Apakah mereka amanah atau aniaya

Namun Engkau menjawab ada hikmah atas keberadaannya

Mereka manusia yang bisa salah juga lupa

Tak ada yang sia-sia bahkan dalam artian dosa

Jika itu jalan penyesalan yang membuat mereka sesal meratap

Kemudian menunduk pulang padaKU dengan penuh harap

114 Sastrawan Covid-19 
Mereka istimewa meski penuh bimbang dan ragu Akal jiwa ruh dan kalbu seluruh bekal kuberi jadi satu Bahkan utusan yang mereka sebut virus itu Hanyalah perantara agar mereka tunduk lagi padaKU

O lihat

Betapa sesungguhnya yang paling merindu Mereka yang ingin kembali

Atau AKU yang ingin ditemui

Pulanglah kepadaKU lagi

Sebagai sosok yang suci murni

Sebagaimana AKU mewelasimu tiada henti

*Penulis, Harista Hidayah Syaifuddin, M.A, adalah dosen di Universitas Islam Negeri (UIN) Sunan Ampel Surabaya, Jawa Timur. 


\section{SECERCAH BERKAH DIMASA CORONA}

Yasyir Fahmi Mubaraq*

Ketika tabir surya menyeruak pagi maret

Ku pikir si mahkota tak akan terbang ke negeri

khatulistiwa

1 purnama lagi kan ku tunggu hadir perhiasan nan jelita Namun telah gugur korban dari mahkota di borneo tercinta

April syaban telah tak kudengar lagi suara panggilan yang biasa

Ku masih menunggu tangisan buah tercinta yang kedua Masih berharap si mahkota hilang dan sirna Namun tak ada daya ku pasrah sambil menunggu si jelita

Hilya akhirnya tiba si perhiasan ku yang jelita Tangis haru dari jauh sang kakek nenek tercinta Tak ada daya tertutup langkah karena mahkota

Annisa ku tercinta telah tiba Namun si mahkota tak tau kapan kan sirna.

*Penulis, Yasyir Fahmi Mubaraq, M.Pd, adalah dosen Pendidikan Bahasa Inggris di STKIP PGRI Banjarmasin, Kalimantan Selatan. 


\section{SENJAKALA MAHARAJALELA}

Sony Sukmawan*

Syahdan,

Di Mejayan, Raden Lo Prawiradipura yang digdaya bertapa mencipta sarana penangkal bala dongkrek namanya kentong, kenong, dan gong pengiringya menghadir lelembut, mengusir pageblug

Di Tengger, Ki Dada Putih yang sakti bermeditasi beroleh tetenger nambak lelakon dihelat, jenang piyak jenang sengkala diijab

taun menahun lenyap, butakala penyap

Di Alas Malang, Mbah Kathi nan mukti bersemedi melantarkan kebo-keboan diarak ider bumi beriring mbok tani, dewi Sri dan para bidadari, Memuja Esa, mengenyah musibah

Di Kalijaga, Syeh Malaya yang wicaksana Melantun kidung cinta, mereksa gulita, memusnah wisa dan gama Teluh sirna, hawar hirap

Di Kita, tanpa keramat dan jimat sapu lidi dan prapen tak lagi pembinasa wabah 
meski dilintang membentang gerbang

selaku dwarapala penjaga gapura

pasukan arwah panembahan senapati tak tersangkal mendekati

Sungguh,

Jenak buat jarak adalah meditasi Ki Dada Putih

Kurung sendiri mengarung diri serupa semedi Mbah Kanthi

Tanjabat salam layaknya sapa indah gita Syeh Malaya

(Didedikasikan untuk para Dukun Pandita dan masyarakat Tengger yang tengah berjuang mengalahkan dampak Covid-19)

*Penulis, Dr. Sony Sukmawan, M.Pd, adalah dosen dan Ketua Jurusan Pendidikan Bahasa Universitas Brawijaya, Malang, Jawa Timur 


\section{SEPI YANG MENGERIKAN}

Rizqi Alif Bachtiar*

Sepi kini kian terasa

Canda tawa disertai prasangka

Kekal menyesakkan nafas.

Kini jarang teralun musik

Terganti berita silih berganti

Dulu kita berdekatan, saat ini saling mempertajam tatapan

Dalam benak menyimpulkan rasa takut tiap detik Jarak satu-satunya pemisah antara kita

Semua dibuat gelisah

Karnamu

Sang perantau tak bisa kembali ke pelukan orang tuanya

Tangis seorang ibu merindukan anaknya

Sang guru hanya menyapa jauh didikannya

Sang pelajar terhalang menerimakan haknya

Suami istri hanya bertatap mukapastikan kesetiannya

Mereka tak terlihat namun sangat mematikan

Bak peluru yang siap ditembakkan kearahku

Atau mungkin, sesungguhnya engkau sudah bersarang didiriku

Entahlah, semua ini membuatku hilang arah

Ku yakin ini semua akan berakhir

Tak ada badai yang akan abadi

Tetaplah berada dirumah 
Bersatulah tanpa saling berdekatan

Berdoalah kau akan mendapat kesempatan lagi

Pasrahlah seolah ini adalah hari terakhirmu di muka bumi

Teruntuk garda depan, lelahmu penyelamat kami

*Penulis, Rizqi Alif Bachtiar, adalah anggota komunitas motor "SUNMORI" Pasuruan dan sedang menempuh studi di prodi Pendidikan Bahasa Inggris, Fakultas Pedagogi dan Psikologi, Universitas PGRI Wiranegara (UNIWARA) Pasuruan, Jawa Timur. 


\section{SERUAN ADZAN MAGHRIB}

Rebbeca Arju*

Pandemi, rasa puasa

Saat berbuka adikku akan meneguk es kelapa

Di gelas monel tua

Lalu mengambil tiga kurma

Menikmati hidangan penuh rasa

Menjedahnya sejenak untuk sujud

Dan kembali icip-icip memenuhi perut.

Tapi ayahku beda,

Beliau minum air putih secukupnya

Berbuka dengan tiga kurma

Bergegas ke musholla

Bermunajat syukur atas puasa yang bahagia

Setelah cukup dengan bakdiyah

Ayah pulang ke rumah

Mengambil sisa menu buka yang masih tersedia dengan

bismillah

Mengakirinya dengan hamdalah.

Ibuku?

Ibu lebih senang berbuka bersama putra/putrinya.

Memanjakan kami dengan menu sederhana.

Namun penuh rasa dan makna.

Meski saat ayah menyantap buka, beliau tetap harus

mendampinginya.

Menghidangkan racikan cintanya. 
Aku sendiri?

Tak tentu...bagaimana aku berbuka pasca puasa corona.

Bahkan mungkin aku tak akan pernah berhenti puasa

Karena semesta pun masih bertahan , berpuasa.

Tapi sedikitpun ku berharap ini akan terjadi selamanya.

Karena setiap detik ibuku terus memasak untuk berbuka, Meski tak tahu kapan adzan maghrib itu tiba.

*Penulis, Barotun Mabaroh, SS, M.Pd, adalah dosen di prodi Pendidikan Bahasa Inggris, Fakultas Pedagogi dan Psikologi, Universitas PGRI Wiranegara (UNIWARA) Pasuruan, Jawa Timur 


\section{SEWANGI NABI}

Prof. Moh. Ali Aziz

Dialah nabi yg kujadikan panduan

kuat dan tegas dalam keimanan, tidak berkompromi dalam keyakinan,

tetapi tetap menjunjung tinggi kesopanan.

Kita bukan hidup di tengah hutan

Tapi dalam masyarakat yg beraneka ragam.

Kita kembangkan gandeng tangan

Seperti kesatuan tubuh dan bangunan

saling menguatkan, bukan saling meruntuhkan.

Ikhlas berkarya bagaikan akar pohon yang tak pernah mendapat sanjungan,

Meskipun selalu mengirim makanan

Untuk semua daun ranting dan dahan

Itulah pribadi sewangi Nabi yang mengagumkan,

Kepadanyalah senyuman Allah teralamatkan.

*Penulis, Prof.Dr. KH. Moh.Ali Aziz, M.Ag, adalah guru besar bidang Da'wah, Universitas Islam Negeri (UIN) Sunan Ampel Surabaya, Jawa Timur dan pendiri Kun Yaquta Foundation. 


\section{SI KECIL...}

Afiyah Wardatul Ummah*

Kecil,...... tak kasat mata

Bagai ledakan bom

Kau buat dunia ini porak poranda

Banyak yang berlarian menjauhimu

Bahkan menjauhi sesamanya

Keimanan diuji

Persaudaraan dan hati nurani ditantang habis-habisan

Kemana aku harus berlari

Dimana aku bisa berlindung

Ya.... Hanya kepada-Nya lah

Sang Maha Cinta aku mengadu

Hingga ku tersadar.....

Kenapa aku harus berlari

"Si kecil" ini datang menyampaikan pesan cinta dari Sang

Pencipta untuk setiap hambaNya

Corona, covid sembilanbelas

Terimakasih karena kehadiranmu

Aku tahu arti persaudaraan lintas batas

Terimakasih karena kehadiranmu

Aku tahu luasnya ruang kreativitas

124 Sastrawan Covid-19 
Terimakasih telah karena hadirmu

Aku tahu cinta yang tulus dan murni tak mudah terhempas Terimakasih karena karena hadirmu

Aku bisa merasakan manisnya iman disertai ikhlas.

*Penulis, Afiyah Wardatul Ummah, M.A, adalah sekretaris Yayasan Pesantren Jauharul Wathan, Cipinang Muara, Kecamatan Jatinegara, Jakarta Timur dan sekaligus dosen di UIN Syraif Hidayatullah Jakarta. 


\section{SIMFONI RINDU}

\section{Zahrotul Muzdalifah*}

Terbangun ku dalam pagi yang teduh

Dengan derap pada guyur dingin air

Berharap dengan kesejukan yang mengalir

Dari simfoni ilahi pada orkestra dzikir

Dalam mihrab kesunyian diri yang fakir

Untaian do'a tak henti untuk diukir

Namun rasaku getir tiada banding

Langkah yang berderap dulu sekarang asing

Dengan ratusan lisan yang kini bergeming

Karena meraka pun sedang mengasing

Juga jalanan legang tiada rungsing

Menjaga dalam spasi yang tanpa pusing

Majelis ilmu yang kini jauh dari indra

Menyisakan rindu dan lara tak terkira

Pada adik-adiku dalam asa mencari ilmu

Juga kawan setia pada KalamNya selalu

tentang tawa riang santri lucu nan lugu

juga tangis padanya ketika merindu ibu

Tentang semua itu..

Aku rindu..

Kini waktu bukan istirahat sayang

Melainkan ikhtiyar,do'a juga sembayang

Pun munajat pada sang penyayang

126 Sastrawan Covid-19 
Untuk ujian corona yang sedang sambang

Dengan menawarkan pelajaran panjang

Pada makhluk bumi untuk tenang

Dan kelak kembali untuk bersyukur riang

*Penulis, Zahrotul Muzdalifah, S.Pd, adalah mahasiswa Magister Keguruan Bahasa Arab Universitas Negeri Malang dan mengabdi sebagai musyrifah Ma'had Darul Hikmah MAN 1 Kota Malang, Jawa Timur 


\section{SURATAN HIKMAH COVID 19}

Eni Ernawati*

Covid 19...

Mendengar namamu, orang ketakutan

Mendengar beritamu, orang jadi putus harapan

Mendengar korbanmu, orang jadi ciut nyali

Mendengarmu seolah-olah semuanya harus berhenti

Kau membawa banyak pesan

Bagi umat manusia

Tak selamanya kesombongan berjaya di dunia

Tak selamanya kemajuan teknologi di atas segalanya

Jika sudah.. Kun Faya Kun!!!

Apa yang terjadi maka terjadilah

Begitu mudahnya Alloh membalikkan telapak tanganNya

Hanya karena makhluk kecil tak kasat mata

Mampu memporak-porandakan dunia

Begitu cara tuhan menegur manusia

Hanya dengan satu makhluk kecil

Mampu mengguncang dunia

Merusak semua sendi kehidupan

Mengahncurkan roda perekonomian

Tapi....

Di balik semua itu

Kau berikan hikmah luar biasa 
Kau satukan keluarga yang dulu hanya bertemu beberapa jam saja

Kau jadikan murid rindu dengan gurunya

Kau buat kami rindu akan masjid

Akan sholat berjamaah

Kau ajarkan pelajaran berharga

Bagi kami semua

*Penulis, : Eni Ernawati, S.S adalah guru Bahasa Arab di Madrasah Tsanawiyah Negeri 5 Kediri, Jawa Timur. 


\section{TAK JADI}

Sofwul Widad*

$\mathrm{Ku}$, sendiri

Tuk mengerti

Dan tanpa letih

Tuk memahami

Walau terlampau lesu rasa dihati

Jika kiranya bunga tak lagi berkelopak,

Burung burung pun kerap melipat sayapnya,

Ku berharap kau kan terjaga walau sejenak saja

Mengakhiri kisah yang kugenggam dengan tanya.

Sarwa semesta

Memaksa laut, langit,dan bumi.

Bergandeng erat, taat, nan bermartabat

Mendesir tiap ombaknya

Menjinjing tiap lapisnya

Lalu entah mengapa manusia semakin kerdil,

Kala raksasa corona bertingkah seakan tak adil

Dan sang dalang hanya sibuk dengan ketok martil

Tempat terindah itu kini

Tak lagi menyayatkan kerinduan.

Hanyalah sabda kepiluan.

Ku menengadah diujung batas cakrawala.

Kala angkasa menghentikan setiap derap langkah..

Begitu banyak persona yang ingin ku lukis,..

Hingga ku tak kenal berapa hati yang telah teriris.

130 Sastrawan Covid-19 
Sajadah mungkin telah bertumpuk bergaris-garis.

Namun hati tetap saja angkuh bengis.

Tak jadikah corona memaksanya terkikis?

Rintik demi rintik, ia dihujat.

Darah demi darah pun mulai menjerit.

Seakan hidup tak lagi ada jalan tikus.

Tuk lari dan lari sejauh mil,

Nan memaksanya tuk duduk sejenak-sejeda nafas.

Ini bukan cerita, bukan juga rentetan epilog kosong tentang corona.

Dan nyatanya kita sama, walau dengan takaran dan kepanikan yang berbeda.

Wahai persona... Ku mohon akhirilah naskah corona.

Bukan sekedar di kertas tertulis yang tak punya daya.

Sejagad hendak mencegah, walau sebenarnya

Corona hanya titik yang tersilap oleh mata.

Namun, saat semua menyadari sungguh kami hanya makhluq yang tak jadi.

*Penulis, Sofwul Widad, adalah mahasiswa di jurusan Pendidikan Olah Raga, Fakultas Ilmu Olah Raga, Universitas Negeri Surabaya (UNESA), Jawa Timur. 


\section{TAMU TAK BERHATI}

Afif Ikhwanul Muslimin*

Sepi sunyi masuk merengkuh nafas

Bening mungil sembunyi tak berbekas

Terbang menari membaur buas

Tak seinsanpun mengerti engkau mengimbas

Hingga temaram panas mengalir deras

Kini tunas dan dahan bertumbangan

Daun hijau, menguning meranggas berjatuhan

Bintik titikmu mengayun mengoyak kerongkongan

Merenggut jutaan yang acuh dan was-was tanpa enggan

Engkau tak pernah terbersit dalam setiap angan

Tetes telah menjadi jelaga mendunia

Pongah dan gagah tak lagi memamerkan raga

Tumpukan koin dan lembar angka bukan segalanya

Beradu kuat dengan engkau dimana-mana

Bahkan rela mengunci kaki dari indahnya dunia

Wahai tamu tak berhati

Insan tak pernah ingin kehadiranmu membumi Mungkinkah engkau untusan pencipta galaksi

Atau hanya daki manusia yang kau cemburui

Hingga kau rela tinggalkan perih dan susah hati

Cerah pagi tak seperti tempo hari

Ramadhan yang suci kau belenggu dalam sepi

132 Sastrawan Covid-19 
Tetes air mata memburu ridho Illahi Rabbi

Rindu sanubari tanpa engkau mengurung kami

Bersimpuh menanti senja tamu tak berhati

*Penulis, Afif Ikhwanul Muslimin, M.Pd, adalah dosen Prodi

Tadris Bahasa Inggris, Universitas Islam Negeri (UIN)

Mataram, Nusa Tenggara Barat. 


\section{TETAP BERTEGUR SAPA}

Santri Kalong*

Mereka yang "terpaksa" pulang kerumah karena tidak ada penghasilan lagi di tanah rantau,

Atau karena sendirian kalau tidak pulang.

Maka jangan kau musuhi mereka,

Apalagi tetangga dekat kita,

Jangan bersikap acuh tak acuh pula,

Tetap bersikaplah hangat,

Meski kudu "social dan physical distancing".

Jangan kau tutup pintu rumahmu secara tiba-tiba,

Mungkin mereka mau menyapa saja,

Atau mungkin juga butuh pertolonganmu sebagai tetangga,

Tetap senyumlah pada mereka,

Tetap bertegur sapa lah,

Walau mungkin tak perlu salaman dan njagong bareng untuk sementara.

Yakinlah wabah ini pasti berlalu dengan segera.

Namun jangan lupa,

Ingatkanlah yang pulang itu untuk tetap dirumah saja,

Tentu dengan senyum manis diwajahmu.

KITA BUTUH SOLIDARITAS UNTUK TETAP BERSAMA.

*Penulis, Hadiqun Nuha, M.Pd, adalah Tenaga Ahli Dewan

Perwakilan Rakyat (DPR) Republik Indonesia, Fraksi

Kebangkitan Bangsa, Masa Jabatan 2019-2024.

134 Sastrawan Covid-19 


\section{TITAH FITRAH KITA}

Win.elkinanti*

pada yang mula

kita kerap bercermin, semestinya.

dalam sepi kita menepi

mendekap gegap-pengap bumi.

dari titik mana pula, setiap kita adalah benih;

rahmat-kasih terberi.

dan......

sebab gagap kita jadi tak tegap-sikap

sebab hiruk-pikuk diri mudah linglung-lalai

sebab pandemi waspada lebih merupa

ketidakpercayaan diri

sebab hasrat menggebu kita kerap ibadat melulu

untuk mengadu-keluh

demikian itu,

yang bisa ku rekap sekena.

setidaknya dalam diri yang sering lalai ini.

wahai jiwa...

menujulah pada yang mula-

kembalilah pada yang fitrah

sebab, setiap yang fitrah adalah

obat yang sejujurnya. 
*Penulis, Winartono, M.I.Kom, adalah Pendamping Desa untuk meningkatkan keberdayaan masyarakat di Kabupaten Malang. Jawa Timur

136 Sastrawan Covid-19 


\section{TOLONG!}

(Tribut untuk para dokter yang membantu menangani

kasus Covid-19)

Lia Laurence*

Tolong,

jangan beri aku karangan bunga yang indah

jangan juga beri aku tepuk tangan yang meriah

Aku datang bukan untuk mengagumi bunga sakura, pun untuk bertamasya

Aku datang bukan untuk menerima sanjungan, pun pujian Aku datang karena jiwa kemanusiaan yang meronta Aku datang karena ingin melayani sesama

Tolong, diam saja di rumah dan biarkan aku bekerja Aku hanya ingin kamu selamat dan tetap sehat Aku pasti akan pulang, jika semua mereda Aku pasti akan pulang, bahkan jika hanya tulang belulangku yang tersisa

*Penulis, Lia Laurence, adalah mahasiswa di prodi Pendidikan Bahasa Inggris, Fakultas Pedagogi dan Psikologi, Universitas PGRI Wiranegara (UNIWARA) Pasuruan, Jawa Timur. 


\section{TRAGEDI UNTUK SI/APA?}

Mundi Rahayu*

Tragedi merambat sekujur bumi

Kadang siklus melambat atau bersicepat tak terprediksi

Menciumi kepedihan, kehilangan, dan kematian

Menyelipkan pembersihan dan kelegaan

Tragedi dan katarsis berjalin berkelindan

Cerah langit setelah hujan petir menyembur ke bumi

Rimbun pepohonan akan menyeruak kembali

Pagebluk menghampiri si hebat dan sesiapa saja Menjungkal si borjuis maupun jelata

Membelit peradaban membulatkan sejarah

Dilantunkan lebih 2500 tahun sudah

Aeschylus, Sophocles, Euripides ucap mantra tak berjeda Shakespeare, Jean Racine, Henrik Ibsen, Samuel Becketts Bertafakkur dalam tragedi panjang bertaut bernas

Para lakon berebut memperjuangkan perubahan

Pengetahuan dan kesadaran adalah kunci

Iba, lara, ngeri terhembus dalam sunyi

membaca nasib takdir dan kehendak ilahi

Tari drama topeng menggaungkan emosi

Berharap faktor $\mathrm{x}$ mengubah akhir

Deux ex machina - berjubah putih berperisai hazmat Menderu mengepal selamat 
*Penulis, Dr. Mundi Rahayu, M.Hum, adalah dosen di Jurusan Bahasa dan Sastra Inggris, Fakultas Humaniora dan Budaya, Universitas Islam Negeri (UIN) Maulana Malik Ibrahim Malang, Jawa Timur. 


\section{YANG TERASA}

\section{Rebbeca_arju*}

Malam hari, kala sunyi

Kau masuk melalui pucuk kuku

Berlari kencang ke terowong organku

Berdesakan dengan tiap sel darahku

Dan kau menetap di tempat yang kau rasa nyaman- untuk menyerang

Ulu hatiku, ekuator tubuhku

Kau hirup kalkogen dari arah kakiku

Bergerilya, memaksa, mencubit-cubit, menusuk-nusuk.

Kakiku kini tak mampu tegap

Hanya bisa tergeser semili dan kaku

Kini bergilir di pusaran perut bumi

Kau semakin menjadi-jadi

Kau urut tiap asam yang ada

Menarik-narik ginjal

Menghimpit erat lambung

Menyayat kantung empedu

Kau pelintir dua belas jari ususku,

Dan aku hampir...tak bertahan.

Kau kian menjadi, meloncat kesana kemari

Dari paru ke jantung, jantung ke paru

Kau menginjak tiap saat katupku ingin terbuka

Menyumbat tiap hembus yang menghidupiku. 
Mulutku terngangah agar dapat meneguk oksigen, namun tetap tubuhku tak berudara.

Aku mulai menangis, inikah ajalku karenamu corona?

Di jantung, kau seperti berhenti menari dan sejenak mendengar protesku.

Dengan ijin siapa kau menjadikanku dulinan

Sedang aku masih memiliki ibu nun jauh

Yang tetes air matanya akan menghujammu.

Tapi kau tak seketika peduli keluhku.

Aku terus menangis, dan kau terus membuat dadaku sesak Mulutku terus terngangah karena hidung tak berdesis

Tanganku tiba-tiba teringat, cepat mengambil sahabatnya sang mushhaf.

Ku tempelkannya di dada, tenggorakan, dan mataku

Aku kian menangis karena dadaku semakin panas

Faring, laring dan trakeaku serasa terbakar

Tibakah ajalku, wahai Tuhanku, hai sahabatku...

Tapi ibuku tak ijinkanku mati dulu...

Air mataku mulai tak mengalir

Epiglotis kini tak mampu menciptakan jarak

Esofagus dan trakea kebingungan dengan apa yang terjadi

Mereka diadu oleh corona, dan saling tabrak dahsyat

Karena sudah tak dapat mendengar instruksi jantungku,

yang lesu; melemah

Tak bisa menjerit, tak bisa apapun,

Corona terlihat hampir menuntaskan tugasnya

menghabisiku

Allahu akbar, inikah ajalku 
Tapi ibuku...

Ibu tak ingin aku mati Tuhan...

Corona telah sampai di hidung, mulut dan terasa di ubunubunku

Tapi hatiku semakin kuat

Aku teriak lantang memanggil Rosulku

Corona makin menghantam, bak tsunami-badai-gempa-

dalam ragaku

Bagaimana ibuku, wahai Rosul

Ibuku...

Aku pasrah sambil terus melafadzkan kesaksian

Berharap inilah kalimat terakhir yang terucap

Yang tercatat

Mataku mulai buram, aku pun menutupnya tanpa harapan.

Ku pasrahkan ibuku padamu, ya Rosul

Usaplah air matanya kelak, karena jenazahku terlarang untuk disentuh

Kesaksian terus ku mantapkan, seakan siap untuk berganti alam

Tak percaya,.... Dalam pasrahku-otw kematianku

Di 01.37, jantungku kembali membentengi-berdenyut

keras

Menentang corona, menghardik, mengusirnya

Neuronku sigap merespon, menyemangati kembali

Memanggil, memerintah setiap organ bekerja-beraliansi

Allahu akbar...

Shollu 'alar Rosul

142 Sastrawan Covid-19 
Terima kasih, tak buat Ibuku sedih

Ruhku melotot memahami bagaimana

Mereka melemah, dan menguat kembali

Ku dapat hirup udara dini ini- lagi

Lakrimalis telah berfungsi - lagi

Ku luapkan, ku ciumi sahabatku yang masih dalam

genggaman

Perlahan kakiku pun mengabarkan telah dapat bernapas

Lara-lara tadi sudah terhempas

Syukurku padamu Tuhan

Dan maafkanlah, tak kupahami selama ini mereka berjuang keras

Menjagaku agar terus sehat, menikmati anugerah hidup ini.

Terima kasih jantungku

Terima kasih tenggorokanku

Terima kasih kerongkonganku

Terima kasih empeduku

Terima kasih lambungku, ginjalku

Terima kasih kakiku, tanganku, mataku dan semua bagian tubuhku..

Kalian adalah ayat tuhan

Yang jarang terbaca

Yang sesungguhnya garda depan sujudku

Hingga nanti saatnya kita akan bersama

Menghadap dengan riang gembira

Menuju kekekalan sesungguhnya - yang bermakna

- selamanya 
*Penulis, Barotun Mabaroh, SS, M.Pd, adalah dosen di prodi Pendidikan Bahasa Inggris, Fakultas Pedagogi dan Psikologi, Universitas PGRI Wiranegara (UNIWARA) Pasuruan, Jawa Timur.

144 Sastrawan Covid-19 


\section{ZONK}

Eeng Zur*

Aku rasa pandemi ini sebuah muqaddimah

Dari rangkaian peristiwa tak menyenangkan

Tapi zonk...

Corona

Memaksa orang menjadi manusia.

Memaksa bumi tetap mewangi,

Memaksa langit, memaksa laut,

Memaksa gunung, memaksa palung

Memaksa fauna, memaksa flora

Memaksa semua

Menjadi bijaksana

Tapi...

Tapi aku tertangis rindu-terhalang corona,

Hingga aku tak boleh bercengkrama

Dengan bunda

Pusara seluruh alam

Tumpuhan hati kala suram.

Dan zonk....

Corona memecut

Dahiku makin mengkerut

Nadi doa bunda selalu berdenyut

Dan, jarak ridlonya lebih terpaut

Restunya tentu tak mengenal ancaman maut 
Mulai ku pahami...

Social distancing, isolasi dan karantina mengedukasi kita tentang uzlah

Pasien dalam pengawasan (PDP) atau orang dalam pemantauan (ODP) hakikatnya adalah berlatih ihsan. Orang tanpa gejala dosa (OTG) pasti lebih berbahaya Karena ia akan mungkin kecewa dengan kurva amal yang ia taksirkan sendiri

Selama di bumi.

Dan kau tahu?

Corona hendak mengakhiri

hendak mengakhiri

ya, hendak mengakhiri

Setiap zonk

Yang kau amini..

*Penulis, Muhsin, SE, adalah owner M99 Manajemen, Pasuruan, Jawa Timur. 


\section{Tentang Editor}

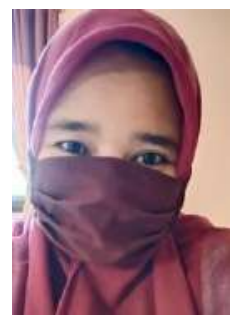

Barotun Mabaroh, SS, M.Pd., dengan nama pena Rebbeca Arju adalah dosen yang aktif mengajar di Universitas PGRI Wiranegara Pasuruan. Ia memiliki intensitas untuk melakukan riset di bidang Pendidikan Bahasa Inggris serta aktif menulis di beberapa media massa. Kecintaannya pada karya sastra khusunya puisi telah dikembangkan sejak menduduki bangku Madrasah Aliyah di jurusan Bahasa. Dalam antologi ini, ia menulis beberapa puisi dan dipercaya untuk menjadi editor dari karya puisi yang telah tersusun di sini. Motto hidupnya adalah "Bermanfaatlah saat ini, bukan nanti, karena nanti mungkin tak kan dapat ditemui". 


\section{Qutologi

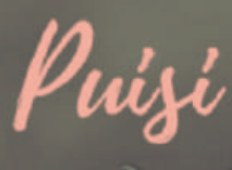

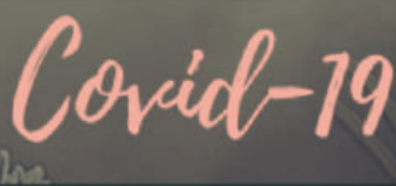

Radang \& Ladang Kehidupan

Antologi Puisi Covid-19, Radang \& Ladang Kehidupan, merupakan kumpulan puisi pilihan yang ditulis oleh masyarakat dengan berbagai latar belakang. Tak dapat dipungkiri, covid-19 membuat semua orang meradang. Akan tetapi, di lain sisi, covid-19 menjadi ladang baru untuk meningkatkan hidup jadi lebih bermutu. Semua pemikiran, gagasan, luapan (ekspresi), dan pengalaman terkait kedua sisi dari kehadiran covid-19 di muka bumi berhasil direpresentasikan melalui 75 puisi di antologi ini. Kompilasi semua karya di antologi dikerahkan oleh tim relawan peduli covid-19 dari M99 Managemen Pasuruan. Antologi ini dipersembahkan kembali untuk masyarakat sebagai media sharing emosi, inspirasi dan motivasi agar tetap bersemangat di masa pandemi. Seluruh karya puisi dalam antologi ini disusun secara alfabetik huruf pertama dari tiap judul puisi. Diksi yang dipilih juga mudah dipahami sehingga masyarakat akan dapat menyimpulkan pesan dan intisari dari setiap puisi. Bait-bait dalam antologi ini juga disusun dengan variasi yang bebas, unik; dengan gaya dan estetika yang menarik. Tak ada gading yang tak retak, antologi ini tentu memiliki keterbatasan dan kekurangan. Namun, ketulusan yang disampaikan oleh para kontributor pada masing-masing puisi semoga dapat meningkatkan semangat diri dan memberi manfaat lebih. Amin.

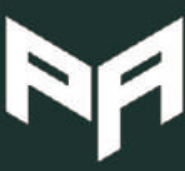

Penerbit Pustaka Abadi (Anggota IKAPI) Ji. Jawa 2-D No.1 Jember, Jawa Timur, 68132 Websile: www. pustakaabadi.com Email: redaksi@pustakaabadi.com

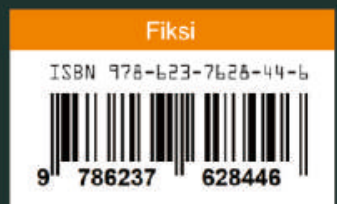

